YONGE AND GREAT: AN ASSESSMENT OF YONGE AS A GREAT STREET

\author{
by \\ John Duy Thanh Nguyen \\ B.A., (Honours) Simon Fraser University, 2015 \\ A Major Research Paper \\ presented to Ryerson University \\ in partial fulfillment of the requirements for the degree of \\ Master of Planning \\ in \\ Urban Development
}

Toronto, Ontario, Canada, 2018

(C) John Nguyen, 2018 


\section{Author's Declaration for Electronic Submission of a MRP}

I hereby declare that I am the sole author of this MRP. This is a true copy of the MRP, including any required final revisions. I authorize Ryerson University to lend this MRP to other institutions or individuals for the purpose of scholarly research I further authorize Ryerson University to reproduce this MRP by photocopying or by other means, in total or in part, at the request of other institutions or individuals for the purpose of scholarly research.

I understand that my MRP may be made electronically available to the public. 


\title{
YONGE AND GREAT: AN ASSESSMENT OF YONGE AS A GREAT STREET
}

\author{
(c) John Nguyen, 2018 \\ Master of Planning \\ In \\ Urban Development \\ Ryerson University
}

\begin{abstract}
Some streets are better than others. Some are ordinary, and others are great. This paper explores what makes Great Streets and the key built form features. A case study analysis was conducted and was guided by an evaluative framework based on Allan Jacobs eight Requirements and five Criteria for Great Streets. The evaluative framework help assessed the degree to which Times Square and Yonge St - between Queen and College - met the Requirements and Criteria for Great Streets. The discussion demonstrates how improvement to the physical Requirements of streets can result in noticeable improvement in its' function. While Yonge is Toronto's 'main street' the evaluation identified areas for enhancement. Specifically, in order for Yonge to be a Great Street, future planning and design strategies should consider the following three Requirements: (1) Places to walk with some leisure; (2) Physical comfort; and (3) Quality Design.
\end{abstract}

Key Words:

public space; great streets; pedestrianization; Toronto; Yonge Street 


\section{Acknowledgements}

I would like to thank Dr. Zhixi Zhuang for offering to help guide me through this study. I grateful for your patience and dedication.

I would also like to thank Christine Fang-Denissov for also taking the time to review my paper and provide such thorough insight.

I am also grateful for the opportunity I had to study here in Toronto at Ryerson's School of Urban and Regional Planning. The professionalism and commitment of faculty and staff here exceeded my expectations. Keep up the good work.

Also, to my family in Toronto, thank you. I am forever grateful and indebted to the support l've had here. I won't forget it. Because of you all, l've been able to call this amazing City my home and classroom for nearly two years.

Thank you mom and dad for the love and support throughout the years. I am in awe and inspired of the perseverance you two display day in and day out. 
Dedicated to Chie. Without you this would not have been possible 


\section{TABLE OF CONTENTS}

Authors Declaration $\quad$ ii

Abstract iii

Acknowledgements iv

Dedication $v$

Table of Contents $\quad$ vi

List of Tables viii

List of Figures $\quad v x$

CHAPTER 1: LITERATURE REVIEW

Overview 1

Public Space for Public Life 3

Streets and Sidewalks, the City's Main Public Spaces $\quad 4$

Streets \& Sidewalks Contribution to Wellbeing $\quad 7$

The Role of Design in Fostering Public Life in Public Space $\quad 9$

$\begin{array}{ll}\text { Conclusion } & 9\end{array}$

CHAPTER 2: CONCEPTUAL FRAMEWORK 11

Great Streets 11

The Five Criteria of Great Streets $\quad 12$

The Eight Requirements for Great Streets 13

CHAPTER 3: METHOD 17

Analytical Framework 17

$\begin{array}{ll}\text { Limitations } & 18\end{array}$

CHAPTER 4: CASE STUDY, NEW YORK CITY 20

Overview $\quad 20$

History of Times Square $\quad 20$

The Pedestrianization of Times Square - Challenges and Opportunities 23

Evaluation of Times Square as a Great Street (Pre-revitalization) 26

Evaluation of the Eight Requirements $\quad 27$

Evaluation of the Five Criteria $\quad 32$

Evaluation of Times Square as a Great Street (Post-revitalization) 34

Evaluation of the Eight Requirements $\quad 34$

Evaluation of the Five Criteria 38

$\begin{array}{ll}\text { Analysis \& Conclusion } & 40\end{array}$

CHAPTER 5: YONGE AS A GREAT STREET $\quad 42$

Preamble $\quad 42$

History of Yonge Street $\quad 42$

Yonge Street Today: Site Context 44

Policy Context - TOCore $\quad 45$

Policy Context - Complete Streets Guideline $\quad 46$

$\begin{array}{ll}\text { Evaluation of Yonge as a Great Street } & 47\end{array}$

$\begin{array}{ll}\text { Evaluation of the Eight Requirements } & 48\end{array}$

Evaluation of the Five Criteria $\quad 54$

Analysis and Conclusion $\quad 57$ 
CHAPTER 6: DISCUSSION AND RECOMMENDATIONS

Discussion

58

Recommendations

59

Conclusions

59

REFERENCES

61 


\section{LIST OF TABLES}

Table 1 The Eight Requirements of Great Streets and Indicators $\quad 15$

Table 2: Qualitative Assessment of the Eight Requirements of Times Square 31

Table 3: Qualitative Assessment of the Five Criteria of Times Square 33

Table 4: The Eight Requirements of Times Square Before Revitalization and After $\quad 37$

Revitalization

Table 5: The Five Criteria of Times Square Before Revitalization and After Revitalization 40

Table 6: Qualitative Assessment of the Eight Requirements of Yonge St 53

Table 7: Comparison of the Eight Requirement between Times Square (prior to 54

revitalization) and Yonge St

Table 8: Qualitative Assessment of the Five Criteria for Yonge Street 56

Table 9: Comparison of the Five Criteria between Times Square Prior to revitalization 56 and Yonge St 


\section{LIST OF FIGURES}

Figure 1: Times Square Project Revitalization Area 20

Figure 2: Figure 2: Pedestrian Injury on Broadway prior to Green Light for Manhattan 24

Figure 3: Green Light For Manhattan Times Square Broadway Lane Closure 25

Figure 4: Times Square Before and After Revitalization $\quad 26$

Figure 5: Broadway Before Revitalization $\quad 28$

Figure 6: Broadway After Revitalization 28

Figure 7: Two-Toned Pavers with Reflective Silver Nickels 31

Figure 8: Massage Parlours on Yonge Street (undated) 43

Figure 9: Yonge Looking North from Queen (between 1978-1983) 44

Figure 10: Yonge Street Development Applications 45

Figure 11: Yonge Street Looking South from Gerrard 48

Figure 12: Yonge Street View Corridor Looking South $\quad 50$

Figure 13: Billboards and Advertisements on Yonge Street $\quad 51$

Figure 14: Blank Building Wall Along the Eaton Centre 52

Figure 15: Yonge Street Looking North towards College $\quad 52$

FIgure 16: College Park Building with the Aura in the Background 53 


\section{CHAPTER ONE: INTRODUCTION \& LITERATURE REVIEW}

\section{Overview}

In the past several years there has been a growing movement and demand in urban civic life for more and better quality public spaces (Kim, 2012; Mould, 2014; Garcia \& Lyndon, 2015). City streets are being redefined and re-purposed into spaces for those on foot, shifting the priority of streets away from automobiles. From transforming on-city street parking spaces into temporary pop-up parkettes, using neighbourhood intersections as canvases for community street murals, and fostering food truck festivals in vacant parking lots, ordinary citizens are leading changes of local streets. Such actions signify a direct challenge to both the use of streets and the shift in focus from prioritizing automobiles to pedestrians and cyclists. And we see the prioritization of public space being implemented by city leaders around the world through progressive policies that are crucial for public social life. Mayor Enrique Penalosa, former Mayor of Bogota, Colombia, boldly transformed the city by prioritizing pedestrians, expanding hundreds of kilometers of streets and sidewalk, and creating new parks and opens spaces. Beginning in 2009 former City of New York Mayor Michael Bloomberg led the pedestrianization of Times Square, effectively removing vehicle right-of-ways along Broadway Avenue across 5-city blocks. Instantly, Times Square went from being a prominent public space without space for people to becoming an exemplary and well used pedestrian- oriented street in the heart of downtown New York. People now are able to cross the street more safely, without overflowing onto vehicle lanes. With 150,000 sf of dedicated public space, the majority of visitors can now not only pass through Times Square, but actually stay, sit, and socialize comfortably.

Here in the City of Toronto we've also seen evidence of streets being redefined. For example, the King Street Pilot project is not only improving commuting times, 
but the restriction on cars has freed up space and opportunity for public realm improvements. The Draft Downtown Secondary Plan, TOCore, has identified 12 "Great Streets", signaling significant future transformations to Toronto's most notable streets: University, King, Jarvis, College, Bloor, Bay, Spadina, Yonge, Queen, Front, and Queens Quay. Importantly the redesign of each will be distinct. Early thinking on 8-lane University Avenue, is to remove two traffic lanes and create an 8.9 acre linear landscape garden park.

Yonge is perhaps the City's most iconic and storied street. Throughout its' history, there has been calls for changes to Toronto's 'Main Street' and more recently, calls for Yonge to be more pedestrian friendly (Downtown Yonge BIA, 2015). The designation as a "Great Street" is the chance for Yonge to be one. From temporary projects of neighbourhood led initiatives to permanent city-wide changes, streets are being reconceptualzied. With an apparent shift in urban values, it is opportune to explore tangible ways to transform Yonge into a Great Street. But what does being a great street mean and what are the benefits of applying this concept to Yonge St? This paper set out to explore and answer 3 questions:

(1) What makes streets Great Streets;

(2) What are the key built form features of great streets; and

(3) What Requirements of street design should be considered for future design strategies of Yonge St?

Allan Jacobs (1993) posits that there are eight physical Requirements that must be present to achieve the five Criteria for Great Streets. This paper created an evaluative framework on the eight Requirements and five Criteria, and then assessed and compared the degree to which Times Square and Yonge St achieved these. Based on the papers observation, Times Square - prior to its pedestrianization - and met four out of eight Requirements except for Places for People to Walk with Some 
Leisure, Physical Comfort and Design Quality. The degree to which Maintenance was achieved was found to be inconclusive due to limitations in assessment. By making improvements to these three Requirements in Times Square, the revitalization also enhanced three out of the five Criteria for Great Streets, making Times Square even Greater. Informed by the lessons learned from Times Square, and the evaluative framework, recommendations for Yonge St were made. In order for Yonge to become a Great Street, future transformation efforts should consider improvements to the following Requirements:

(1) Places for People to Walk with Some Leisure

(2) Physical Comfort; and

(3) Quality Design

\section{Public Space for Public Life}

Public space is commonly viewed idyllically as an 'open arena' for everyday life. Most simply, the basis of being public refers to both openess and accessibility for all. Kohn (2004) propose that "in everyday speech public space usually refers to a place that is owned by the government, accessible to everyone without restriction and/or fosters communication and interaction" (p.9). Legally, it is accessible to anyone (Lofland, 1973). It may not be obvious but without public space it would be impossible to perform the simplest of daily tasks. Imagine the challenge of commuting to school without a trail, road, or sidewalk to freely access. These spaces provide a platform for a range of possibilities to the mundane encounters with strangers to mass demonstrations calling for social change, and perhaps it is the range of possibilities that they are viewed as critical spaces in our cities. Mandanipour (2010) observes that public space has had and will continue to have an integral role in the evolution of human settlement. 
Observing how public space was used historically reveals its' complexities and evolving nature, something that continues to be in flux today. They are barometers of a city's politics, and socio-economic condition; how public spaces are formed and used provides a reflection of the political, economic, and social concerns of our time (Varna, 2014).

Most often cited as the idealized public space is the Greek Agora of ancient Athens (Lang \& Camp, 2004). It consisted of a large open square and functioned as a multiuse area, a site for markets, contests, and festivities for its citizens (2004). Symbolic of the democratic aspirations at that time, most importantly, the Greek Agora was a site for dialogue and debate where the public was open and encouraged to speak freely without repercussion; diversity of views and uses produced a vibrant public realm which was a critical component of a healthy democracy (Watson, 2006).

Living in the city, one is to accept a life that is immersed in difference and intimately surrounded by strangers. The stage upon which this occurs are our urban public spaces which fosters an environment where millions of strangers are able to live in a functioning coexistence (Lofland, 1973). The ease in which social connections and interactions are able unfold in public spaces indicate a quality of urban social life (Young, 1990). It is through the open use, communication and social relations established in markets, streets, squares, and parks that places attain importance for the collective public (Goheen, 1994) while individual social needs are fulfilled by the culmination of ephemeral contact (Mehta, 2014).

Public space permeates through everyday life and it's unsurprising that its conceptualization and significance varies widely. Most critically, however, is the underlying ideal of public space being open and accessible providing the required starting point and platform for which social life functions.

\section{Streets \& Sidewalks, the City's Main Public Spaces}


"Streets and their sidewalks, the main public spaces of a city..." (Jacobs, 1961, p.37) as renowned urbanist and activist Jane Jacobs proclaims, “....are its most vital organs" (p.37). Streets establish the city's foundation, are the most plentiful and accessible public spaces and inseparable from the city's image. Jacobs asks, "Think of a city and what comes to mind? ... Its streets". Her observations of the "sidewalk ballet" along the short Hudson Street block where she lived, celebrated streets as a foci for the city's vitality and diversity. They are the stage upon which everyday life unfolds. Jacobs description of how cities function on the ground starkly contrasted with the planning theory of how cities "ought to work" at the time. Jacobs' meticulous observation of the seemingly mundane was far from the grand designs of parks, open space, and sleek boulevards of Master Planners. The objectified built environment - showcased in post-war urban renewal design - revealed a belief in architectural determinism and much less concern for social life (Southworth, 2014). But throughout human civilization streets have been central gathering places (Gehl, 2011) and frame the form of buildings (Jacobs, 1993). It is the most important element of the built environment (Appleyard, 1981). It's common to observe a complex range of uses, users, and needs on streets. The public right-of-way must balance multiple needs above, below and at grade, including the mobility of cars, bikes, service vehicles and transit within roadways, and the movement of pedestrians along sidewalks, and the provision of services, utilities and public realm elements like landscaping, street signage, and street furniture. Arriving at a balanced street that satisfy the needs of different users is challenging. Viewed as a place for living and as a space for access streets have long been sites of friction between livability and transportation as Appleyard (1981) states: "The street has always been the scene of this conflict, between living and access, between resident and traveler, between street life and the threat of death" (p.1). In his analysis of three neighbourhood residential streets in San Francisco, Appleyard (1981) revealed a stark contrast in level of social interaction, depending on the level of vehicle traffic. Residents 
living on traffic heavy streets had 3 times as less local friends and twice as less acquaintances than those living on traffic light streets. Through the concept of 'ecology of streets' Appleyard (1981) put forth the importance the of understanding the needs of different users in-order-to mitigate vehicle-pedestrian conflict and enhance the liveability of residential streets.

Much like public squares and streets, sidewalks are also sites of negotiation and conflict (Ehrenfeucht, 2017). The activities that which makes sidewalks vital arenas for activity simultaneously invokes a problem to be resolved. Streets are often viewed as a functional and neutral space that should be clearly delineated and designed for unimpeded flow. But this idea, however practical, undermines the social and political nature of streets (de Vasconcellos, 2004). Traffic logic, according to Blomley (2007 \& 2011) frames sidewalk use as space for unimpeded travel. Particularly, order, clearance, unobstructed movement, and regular maintenance are prioritized on sidewalks (Blomley, 2007 \& 2011; Ehrenfeucht \& Loukaitou-Sideris, 2010). Ensuring a clear pathway for travel is undoubtedly sensible, however Blomley (2007 \& 2011) argues that traffic logic, enforced through the design and regulation of sidewalks overly constrains activities and oversimplifies users as 'pedestrians'; objects, including people that obstructs the right of way are seen as simply traffic barriers. The ordinances that are in effect today are a product of planners and engineers committed to the simple goal of pedestrian flow (Blomley, 2007). The historical relationship between the two professions, despite policies that are in place to improve pedestrian conditions, are according to Hess (2009), a primary barrier to improving streets for people. Hess (2009) calls for a change in how streets are designed and built if city administrators are truly committed to expanding the role of public streets. While safety and minimizing risk to injury should be a priority, strict adherence to lane widths, turning radii, etc, limits the extent to which the pedestrian experience can be improved (2009).

For Jacobs (1961) rather than viewing sidewalks simply as a traffic corridor, she 
observed its vital role in facilitating the seemingly trivial yet critical contact amongst strangers. Instead of functioning in an orderly manner, simple actions or 'tactics', exercised by users regularly break the rules and resist the 'strategies' of administrators (Certeau, 1984). What needs to be uncovered is the manner in which people actualize their surroundings which has traditionally been an afterthought in the city planning process (1984). Planners are situated in a paradox. On one hand the role of planners it to regulate and organize activity such as delineating zones for pedestrian traffic, street furniture, vending, and newspaper boxes. On the other hand, sidewalks are often not predictable spaces but rather are sites of spontaneous and conflicting behavior (Ehrenfeucht \& Loukaitou-sideris, 2010). While regulation of public space by city ordinances are a common feature today, civic leaders and administrators in midnineteenth century City of Toronto were quite restricted in their ability to control public space (1994). Attempted changes to its use were contested vehemently by a public that assumed a sense of authority to ensure the right to access (1994).

Streets and sidewalks are the most accessible and widely used public spaces. How they are planned for demands consideration of wide ranging uses and users. As urbanization and a shift towards a more complex population shapes the everyday life of cities, planners are challenged to expand their notions of streets and sidewalks and plan in a manner that not only acknowledges their complexity of uses but embrace it (Ehrenfeucht \& Loukaitou- sideris, 2010).

\section{Streets \& Sidewalks' Contribution to Well-being}

Social life is shaped by everyday spaces like streets, sidewalks, and parks (Rannila \& Mitchell, 2016) and over the years public space has been identified as a contributing factor to health and wellbeing (Catell, Dines, Gesler, and Curtis, 2008). Parks and open spaces have long been identified as contributing to mental and physical 
health and are one of the most important factors for successful ageing (WHO, 2007). They have also been found to enhance overall quality of life for older adults (LoukaitouSideris, Levy-Storms, Chen, Brozen, 2016). As much as social interactions have been a part of city life, public spaces have played a central role in facilitating it. While numerous benefits are attributed to public spaces an underlying theme across literature is the description of the social function of plazas, parks, markets, and streets; and for some (Metha, 2014), sociability is its most important role.

Certain aspects of public space can provide the opportunity for social capital allowing for supportive group participation and bonding (Catella, Dines, Gesler, and Curtis, 2008). Social capital is defined to be 'the features of social organization - such as trust between citizens, norms of reciprocity and group membership - that facilitate collective action" (Kawachi et al., 1998 \& Putnam, 2001 in Muzamdar et al, 2018, p.21) and speaks to group bonds within supportive communities and the quality or intensity of social ties between individuals. Not only important for individual wellbeing, such ties compound into broader community benefit as social links provide the prerequisite for the development of a sense of community (Peters, Elands \& Bujis, 2010). Even the most fleeting of encounters are recognized as significant (Goffman, 1963).

Catell et al (2008) highlights that social dimensions of publicly accessible spaces positively contributes to overall wellbeing. Through interactions with friends, acquaintances and strangers, public squares, parks, and open markets can provide a space that is essential to one's sense of well-being (2008). Catell et al (2008) used the World Health Organization concept of well-being, defined as 'a state of physical mental and social well-being'. Dines et al (2006) cautions that design in of itself does determine one's well-being, rather "they possess subjective meanings that accumulate over time..." (p.39). That said, Dines et al (2006) advises that the contribution to well-being and the therapeutic properties of public space should be recognized and explored. 


\section{The Role of Design in Fostering Public Life in Public Space}

Essential to any city is a vibrant city centre, one that fosters outdoor public life, and that attracts local residents, visitors, and tourists to not only pass by but importantly, to stay and spend time in (Gehl \& Gemzoe, 2004). Gehl and Gemzoe (2004) observes that there are two distinct social activities. The first are necessary, activities that people have to do. The second form of activities are optional. These are activities people partake in because they want to (2004). The distinction between the two is important because optional activities are the first indication of the ability of public space to attract and retain people (2004). Metha (2007) suggests urban design characteristics can be applied to the planning and re-design of successful neighbourhood streets. Particularly, physical quality of the built form and land use are factors that can encourage people to stay and linger in a space or to continue walking by (2007). Furthermore, the types of uses, walkability of places, preference and urban design elements all contribute to the quality of streets but it's important to highlight that such factors do not function independently of each other or of existing policies and management schemes (Mehta, 2014).

\section{Conclusion}

The literature review describes the concept of public space, streets and sidewalks and their critical role in the functioning of society. Though the concept of public space varies, it's clear that it provides an essential service to cities, one of which being, fostering social life. Streets and sidewalks form the basis of public space and enable open access and movement for everyone. These are places for citizens to see the diversity of their city, and be exposed to new sights and sounds, in a manner that allows them to be anonymous but at the same time included in society. Inclusion, being part 
of a broader community is critical to social wellbeing. How then does public space, particularly streets, influence positive social life in cities in a manner that balances different needs? With downtown Toronto intensifying, so too are the pressures on its basic infrastructure. Street furniture, trees, and bicycle parking posts will likely become obstacles and compete for space with the sheer number of people on streets. One way the City intends to address this is to improve and expand streets and sidewalks. The 12 great streets identified by TOCore (City of Toronto, n.d.) have a pivotal role in increasing quality of life and are targeted for public realm improvements. What improvements will occur will depends on the context of each street. This paper intends to explore the concept of great streets in detail and how it can be applied to Yonge. 


\section{CHAPTER TWO: CONCEPTUAL FRAMEWORK}

This section explores in detail the concept of great streets, a term popularized by Allan Jacobs (1993). The purpose here is to identify what specifically are the indicators of great streets, as identified by Jacobs (1993). These indicators will then be applied to the analysis of New York City and inform design solutions to transform Yonge street.

\section{Great Streets}

There are reasons why some streets are better to on than others (Jacobs, 1993). According to Jacobs (1993) great streets firstly help make community. They are the most desirable places for people to socialize, live, and work. They are settings that allow people to come together. And important to successful streets are the consideration of physical and designable elements. It should be clear however, that while important, thoughtful design does not determine lively spaces; in contrary, vibrant public life can occur in under-designed or vacant spaces such as laneways and parking lots (Southworth, 2014). And Jacobs (1993) acknowledges the difficulty in proving outcome, but nonetheless, exploring the physical elements of what makes streets function well will certainly help inform future design decisions. Jacobs (1993) compiled a list of great streets from countries around world, that starkly differ in form, function, and surrounding context, and details the physical elements in a manner that invites comparison and analysis between each.

For example, Roslyn Place, Pittsburgh is a historic and unassuming residential street. The compactness of the physical elements at Rosyln Place work together in a manner that help foster a sense of intimacy and physical comfort on the street (Jacobs, 1993). Cars parked on both sides of the lane help enclose an already narrow street, discouraging vehicles from speeding (1993). Homes are bunched together and are similar, yet unique in architectural design (1993). The street-lined trees contribute help ensure comfortable microclimates year-round (1993). One other example worth 
highlighting is a once great street in San Francisco. Jacobs (1993) describes the changes on Market St in a manner that reveal the failings of design. In the 1930s it was a destination with a variety of thriving business, entertainment, shops, restaurants that immediately addressed the street (1993). Street cars set the pace of the area, by bringing the large physical presence of people yet at the same establishing a speed that was safe and pedestrian friendly (1993). But over time the number of small-format shops and buildings declined, as scale of buildings and uses became larger (1993). Large anonymous office buildings with ground lobbies now deflect attention instead of capturing the eye with the interest of small local shops (1993). In this example, Jacobs (1993) describes the outcome of built forms that did not consider human scale and interesting design. Jacobs (1993) emphasizes this lesson as states "it seems that most severe changes, the ones that have made the difference between a great street and a less great one are those that have lessened community focus on Market Street while at the same time diminishing individuality and interest” (p.89).

It may seem impractical to learn from two distinct cases such as a quiet residential street and a busy downtown main street. But in these two examples one can elicit clues to what makes a street work well for pedestrians - or use to, in the case of Market St. The sense of safety and comfort are present in Roslyn Place and 1930s Market St; residents/pedestrians are at more ease when overall mobility is slowpaced; defining architectural elements character homes and uniquely styled downtown buildings stimulate visual interest; and the smaller buildings fostered a built form scale comfortable for street users. The social, cultural, and physical context of the best streets will vary and so do their design elements. In short, Great Streets are tied together by both form and function.

\section{The Five Criteria of Great Streets}


Speaking to how Great Streets should function Jacobs (1993) provides five Criteria and states that Great Streets should:

(1) Foster community: Great Street should firstly provide for a setting that attracts people and be sites to see and hear others of all kinds. A Great Street should be the central focus of an area, a destination for all types of experiences, such as living, working, playing and socializing.

(2) Be physically comfortable and safe: Great Streets are physically comfortable and safe in perception and reality; pleasant micro-climates such as shade during summer days or bright open spaces during the colder winter months help create a more enjoyable walking environment and alleviating concerns of being struck by vehicles is top safety priority.

(3) Encourage participation: Great Streets allow for both active and passive participation for users of all ages. They are sites for sitting and people watching and at the same time, a play area for children or a parade. There exists a malleable role of Great Streets that suits the different needs of people at any given time.

(4) Be memorable: Great streets make a lasting and fond impression and are desirable for people to revisit.

(5) Be representative or symbolic: Great streets are symbolic and representative of an idea or thing beyond the Street itself. Whatever it is symbolic of, Great Streets achieve a certain status that is widely known.

\section{The Eight Requirements for Great Streets}


The section prior outlines how great streets should function, but what are the necessary design features that makes this possible? Though there are many contributing factors Jacobs (1993) provides a list of mandatory physical Requirements. The 8 Requirements for Great Streets are as follows:

(1) Places for People to Walk with Some Leisure.

The best streets make travel comfortable, safe, and pleasant for those on foot. Every Great Street Jacobs (1993) describes in his book share the seemingly basic common quality; they enable safe, comfortable, and leisurely walks.

\section{(2) Physical Comfort}

People seek out physical comfort in response to unfavourable weather conditions. Great Streets are comfortable physical setting and provide for shade on hot sunny days, or sunlight during colder seasons. The challenge here is to protect or enhance certain elements in a manner that does not offset the benefits of the natural environment. (3) Definition

Streets need to be communicated clearly. Vertical and horizontal definition. Streets cannot be too wide or else it loses the opportunity to be defined. Jacobs (1993) identifies buildings generally provide definition at street cross section design ratio of one (building height) to two (width of road).

(4) Qualities that Engage the Eye

Visual complexity help make streets appealing. Part of what makes streets successful is the facilitation of moving objects - cars, people, leaves blowing in the wind, tree canopy - and structures through the changing of casted light.

Transparency 
Transparency speaks to the seamless integration of private and public realm. Adequate transparency is achieved when one has a sense of what's behind a street wall and are invited in by large glass windows and doors that meet the street.

\section{(6) Complementarity}

Complementary buildings help reinforce character. Buildings are not to be identical but respect each other aesthetically and in form; there should not be drastic differences in façade treatment, building height or width between buildings.

\section{(7) Maintenance}

Maintained streets and buildings are important characteristics and it is both the cleanliness and quality that invoke a sense of care.

\section{(8) High Quality Construction and Design}

Workmanship, materials chosen and how they appear in the product of design speaks to a sense of care and thoughtfulness or lack thereof. The key consideration is the appropriate use - not the high cost - of materials.

The evaluative framework describes the built form components and function of Great Streets as informed by Allan Jacobs (1993). The following table (Table 1) summarizes the 8 physical Requirements for Great Streets coupled with their key indicators:

Table 1 The Eight Requirements of Great Streets and Indicators

\begin{tabular}{|l|l|}
\hline Requirement & Indicators \\
\hline $\begin{array}{l}\text { Places for People to Walk with Some } \\
\text { Leisure }\end{array}$ & $\begin{array}{l}\text { - Pathways for walking at different paces } \\
\text { No overcrowding of sidewalks and } \\
\text { spillover onto vehicle lanes }\end{array}$ \\
\hline
\end{tabular}




\begin{tabular}{|c|c|}
\hline Physical Comfort & $\begin{array}{l}\text { - Favorable micro-climate conditions (i.e. } \\
\text { sunlight and warmth in winter; shade } \\
\text { during summer days) }\end{array}$ \\
\hline Definition & $\begin{array}{l}\text { - Street width, Street height, Topography, } \\
\text { Visual intrusions } \\
\text { - } 1: 4 \text { height to horizontal distance ratio } \\
\text { when looking across the street at a } 30 \\
\text { degree angle (Broadly building heights } \\
\text { that are half the width of the entire } \\
\text { street) } \\
\text { - Cross section design ratio of } 1: 2 \text { in } \\
\text { height to width } \\
\text { - Limited horizontal spacing between } \\
\text { buildings }\end{array}$ \\
\hline Qualities that Engage the Eye & $\begin{array}{l}\text { - Slow moving vehicle traffic } \\
\text { - Presence of people } \\
\text { - Complex building facades (i.e. colour } \\
\text { vertical breaks) }\end{array}$ \\
\hline Transparency & $\begin{array}{l}\text { - Highly visible, transparent and inviting } \\
\text { windows and doorways }\end{array}$ \\
\hline Complementarity & $\begin{array}{l}\text { - Overall similar and reinforcing, yet } \\
\text { distinct building character (height, } \\
\text { setbacks, step backs) }\end{array}$ \\
\hline Maintenance & $\begin{array}{l}\text { - Overall cleanliness of streets and } \\
\text { buildings }\end{array}$ \\
\hline Quality Design & $\begin{array}{l}\text { - High quality construction and finish of } \\
\text { streets and buildings }\end{array}$ \\
\hline
\end{tabular}

To summarize, the eight Requirements and 5 Criteria for Great Streets will be used as an evaluative framework to assess the degree to which the pedestrianization of Times Square is a Great Street. In addition to the eight Requirements and five Criteria, the lessons learned from Times Square will be applied to the evaluation of Yonge St from which recommendations will follow. The conceptual framework is not intended to capture complete knowledge of the case. It narrows the focus with emphasis on physical Requirements which can help future street transformation projects in Toronto. 


\section{CHAPTER THREE: METHOD}

The purpose of this paper is to develop an in-depth understanding about the pedestrianization of New Yok using a Great Streets framework and apply lessons learned to the Yonge St. Case studies allow for an intense but flexible study of a particular phenomenon within a "bounded system or multiple bounded systems over time... involving multiple sources of information" (Cresswell, 2007, p.245). It involves an exploratory process of discovering relevant and reliable information sources on a given phenomenon in relation to its context. But both case and context does change over time, presenting innumerable variables to measure and thus increasing its complexity for analysis (Yin, 1999). Identifying Great Streets involves the challenges of accessing necessary and multiple data sources. This paper will use predominantly secondary sources such as archival records and other documentation. And since the author could not visit the site the use google maps and street view will be relied upon for the assessment of Times Square. This research will investigate Times Square, in New York City and examine the process, rationale and outcome of the pedestrianization of the formerly auto-oriented street. The lessons learned in New York will help inform the recommendations to transform Yonge St.

\section{Analytical Framework}

The paper had set out to answer the following questions: What makes streets great streets and what are key built form features of great streets? What street design requirements should be considered for design strategies of Yonge St?

The case study analysis is guided by an evaluative framework based on Jacobs (1993) eight Requirements and five Criteria and will be used to explore the relationship between meeting the eight physical Requirements and demonstrating the function as 
a Great Street. The focus of the case study will be on the pedestrianization of Times Square, however an assessment of Times Square before the permanent street changes will be conducted as well. The following steps will be taken to assess New York City's Time Square prior to and post pedestrianization.

(1) To what degree does Time's Square meets the eight Requirements for Great Streets. A qualitative scale will be used to identify whether each of the Requirements is (a) achieved very well; (b) somewhat achieved; and (3) not achieved.

(2) Secondly, how successfully does Times Square meet the five Criteria for Great Streets. In other words, how well does the street function? Similarly, the degree to which the five Criteria are met will be assessed with the following qualitative scale (a) achieved very well; (b) somewhat achieved; and (3) not achieved. In addition to secondary source data, existing surveys of users of the square will be sought and relied upon.

(3) Analysis and discussion will then follow as to assess the extent to which the pedestrianization of Times Square functions as a Great Street.

\section{Limitations}

The research direction is relatively open in nature and while one of the benefits of case study research is a flexible approach, flexibility does have limitations. Data sources are limited to primarily two sources: documentation - reports, journals, government websites - and observation via google maps and street view. The ability to rely on data from various sources is particularly helpful as a means to substantiate information. But assessment of the case study depends significantly on a subjective review by the author. Google street view is advantageous as it allows the author to explore a site 
without actually visiting it. And viewing images is not the same as experiencing a space on the ground. The method posed here attempts to offset the limitations described above by using a conceptual framework that will help guide the description and analysis of the case. 


\section{CHAPTER FOUR CASE STUDY: TIMES SQUARE, NEW YORK, USA}

\section{Overview}

This chapter will examine the pedestrianization of Times Square that first began as a pilot project as Greenlight for Midtown and resulted in a permanent redesign overseen by design firm Snohetta. The pedestrian project area and focus of inquiry is Broadway and 7th avenue between West 47th Street and West 42nd Street (See figure 1). The project area extends just under 400 metres in length. It's important to note that the Green Light for Midtown initiative was a part of a much broader effort to expand NYC's parks and public space network under PlaNYC (City of New York PlaNYC, 2011). One area of focus was transportation and through World Class Streets (WCS), NYC's Department of Transportation (DOT) led the transformation of NYC streets into more safe and appealing public spaces for pedestrians, a shift of focus from a department that up until 2007 was chiefly concerned with vehicle traffic management (Luberoff, 2016). The DOT has since led the development 70 plaza from what use to be street right-of-ways and expanded the bicycle network by adding over 400 miles of Figure 1: Times Square Project Revitalization Area interconnected lanes (2016).

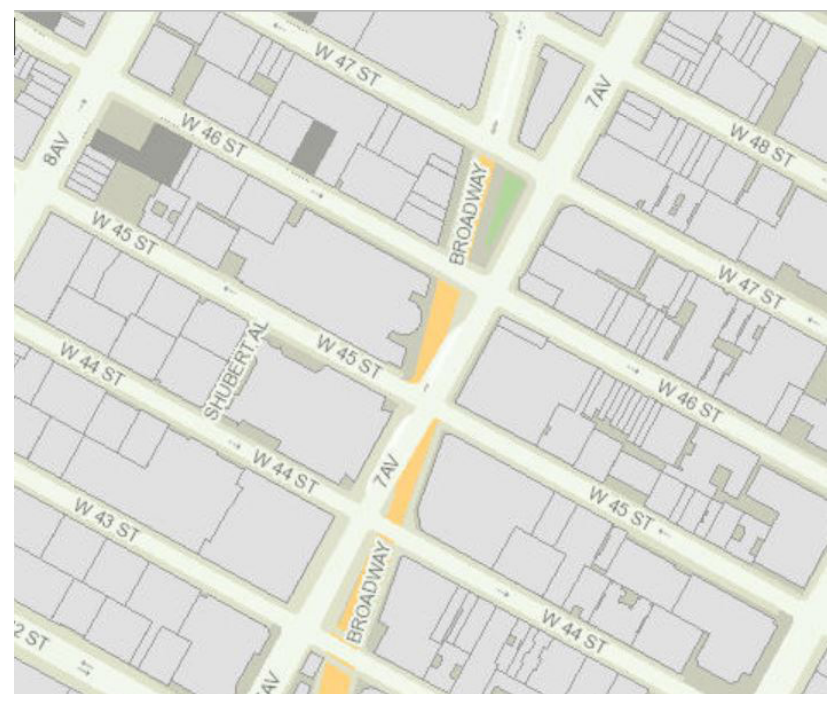

Source: http://maps.nyc.gov/doitt/nycitymap/

\section{History of Times Square}

The history of Times Square provides a reflection of the technological advances, cultural shifts and challenges that occurred throughout other U.S cities (Makagon, 2003). It provides a barometer 
into how public participation is viewed and experienced in contemporary life (2003). Located at the intersection of Broadway and Seventh Avenue in Midtown Manhattan, Times Square extends north-south along from 47th to 42rd St with Broadway diagonally cutting through the traditional street grid, establishing the shape and befitting moniker, the bowtie. Far from the major tourist major attraction it is today, Times Square in 1904 "consisted of a large open space surrounded by drab apartments" (Times Square NYC, n.d). With the introduction of electricity street lights and advertisements began to liven Times Square and make it more inviting. And by World War One, Times Square served as the primary theatre and entertainment district. West 42nd St became a central transportation hub by the 1920s serviced both subway and elevated lines along with several bus routes.

Times Square drastically altered with the advent of the Great Depression. The theatre and entertainment struggled and was eventually predominantly replaced by lower and seedy forms of entertainment and prostitution. No longer the entertainment hub of 1920s, from then on Times Square throughout the decades became known for facilitating varying degrees of adult entertainment and merchandising, open drug transactions and use, as well as crime. At its peak, there were 140 recorded adult establishments (Times Square Alliance, 1996). But the crack cocaine epidemic 1980s may have signaled the areas lowest point as addicted crack users, dealers and poverty became a mainstay.

The mid 1990s marked a stark contrast to the previous decades. The NYC police department initiated a directed crime prevention program - Compstat - where after violent crime fell (Luberoff, 2016). And major transportation investments were made by both state and federal governments that saw significant upgrades to rail and bus services (2016). A 1996 Annual Report from the Times Square Business Improvement District reveal, that Times Square was headquarters for several large multimedia and financial companies. "Supersign" billboards were going for up to $\$ 1.2$ million/year. 
21 million square feet of office and 1.3 million square feet of retail space signaled a healthy economic environment. During the nineties the City also made concerted effort to revitalize the social and cultural assets of Times Square, and offered tax incentives for new businesses to kick-start a sense of economic stability in the area (Radywyl \& Biggs, 2013). The Walt Disney Company was a key player in igniting the turnaround. When it had stated interest in purchasing the New Amsterdam theatre in Times Square, the area was still deemed to hostile for the Walt Disney Company to be the only new business on the block; so the City offered the company a low-interest loan in addition to persuading the City to strike deals with two other companies to move in: Tussauds wax museum and AMC Theatres (Bagli, 2010). Soon after restaurants and movie theatres begun to open up and critically new development followed signifying economic renewal that was pivotal to Times Square's transformation (2010). But city efforts may have been too successful in drawing businesses and tourists as the late 90s depict a dangerously congested Times Square mixed with vehicle traffic, daily commuters, and tourists (Radywyl \& Biggs, 2013).

By the 2000s, Times Square had appeared to have taken a complete 180 from its troubled past, establishing itself as an attractive destination to live, work and visit for residents and tourists. Whereas the population declined by $10 \%$ to $7.1 \%$ in the 1980 s NYC was now home to over 8 million residents largely driven by growth in the finance and business sector (Luberof, 2016). But the intensity and flow of users and uses produced a different challenge. The mix of public transit, cars, cyclists, and pedestrian slowed traffic, greatly disrupting the flow of travel in the area (City of New York, n.d.). Along with traffic congestion, NYC's population growth became increasingly evident in the growing crowds and noise. The growing demands on New York City's basic infrastructure and challenge to accommodate future growth encouraged the City to explore strategic land use planning (Luberoff, 2016). Among others, the lack of parks and open space to provide for residents was a concern compounded by high land costs 
that by and large restricted the City from purchasing land for park space (2016).

In April 2007, NYC Mayor Michael Bloomberg publicly introduced PlaNYC: Greener, Greater New York, that set out broad goals with 127 separate initiatives. Limited by land constraints, PlaNYC advanced innovative ideas such leveraging existing public assets to expand its parks and open space network. For example PlaNYC explored opportunities to open school yards across the city as public play grounds, convert asphalt into turf fields and enhance public plazas in every community. Emphasis was added on repurposing underutilized spaces across the city and ensuring that all New Yorkers lived within a 10-minute walk of a parks and public spaces (City of New York PlaNYC, 2011). As a result several existing plazas were revitalized and new 'interim' plazas were launched in underutilized streets using low cost materials such as paint and plastic barrels. Pivotal to the launch and direction of PlaNYC was the appointment of Jannette Sadik-Khan as Commissioner of the Department of Transportation. With Sadik-Khan's leadership, the City's streets underwent transformative change with the expansion of pedestrian plazas, hundreds of miles of new bike lanes, and a launch of a bike-sharing program (2011).

\section{The Pedestrianization of Times Square - Challenges \& Opportunities}

In 2006, before its redesign, Times Square encompassed 183,000 sf along with 20,200 sf of pedestrian only area. This meant that $90 \%$ of the area was dedicated vehicle space (Gehl, 2008). Street width ranged from 69-102 feet, while sidewalks width ranged from 14-20 feet (2008). This stood in stark contrast with the fact that $90 \%$ of the people who used the space were pedestrians (Gehl People, n.d.). The irregular street grid and volume of traffic contributed to concerns over pedestrian safety. Narrow medians provided insufficient space for pedestrians and were often dangerously overcrowded (Times Square 2006- 2007, n.d.). Not only creating a confusing traffic pattern, the intersection of Broadway and 7th Avenue created an 
Figure 2: Pedestrian Injury on Broadway

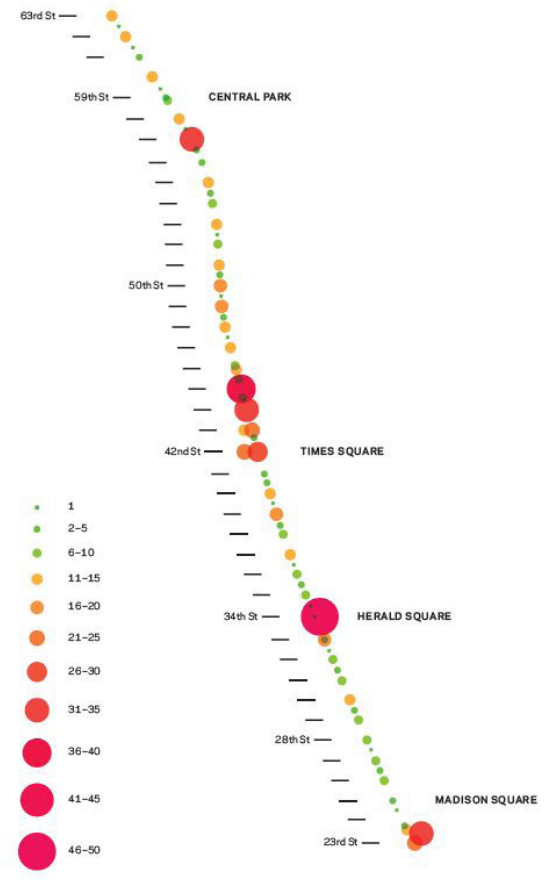

Source: $1 \mathrm{http}: / /$ www.nyc.gov/html/dot/downloads/pdf/broadway_report_final unusually long crosswalk for pedestrians to walk along. The imbalance in use and limited amount of space contributed to an unfriendly environment that increased pedestrian-vehicular conflict (See Figure 2). Pedestrians in and around Times Square were struck by vehicles at a drastically higher percentage - $137 \%$ - than adjacent avenues (Sadik-Khan \& Solomonow, 2017). Particularly, Broadway Ave at 7th Avenue was a chief concern; between 20022004, there were 91 recorded collisions between pedestrians and vehicles (Times Square Alliance, 2008). The nonprofit organization, Project for Public Spaces, conducted a site assessment of Times Square and one of the more glaring observations made was the fact that there was not a square there to support different activities and uses (Times Square 2006-2007, n.d.). The following list provides a select list of issues identified by the Times Square Alliance Problems and Possibilities Report (2008):

- $\quad$ No spaces for stationary activities in Times Square

- Public safety risk due to spillover onto road space

- Pedestrian congestion and limited pedestrian mobility

- Safety due to risk of vehicle-pedestrian collisions

Pedestrian safety in Times Square was not just limited to Times Square. As discussed earlier, the City of New York recognized the growing challenges with a growing downtown population and the increasingly crowded streets and produced PlaNYC to developed plans to manage new growth. PlaNYC also outlined goals for transportation focused initiatives. In 2008, New York's Department of Transportation released its 
first ever strategic plan, Sustainable Streets, 2008 and Beyond (City of New York, 2008) a broad transportation focused policy. The plan set out 164 actions to improve mobility and critically it explicitly established pedestrian-oriented and bicycle-friendly streets policy (2008 and recognized streets as vital public spaces necessary for City's overall quality of life.

Directed by Sadik-Khan the strategic plan put forth policy guided goals and sought to improve pedestrian movement and safety on New York City streets with key objective such as: cut traffic fatalities by $50 \%$

Figure 3: Green Light For Manhattan Times Square Broadway Lane Closure

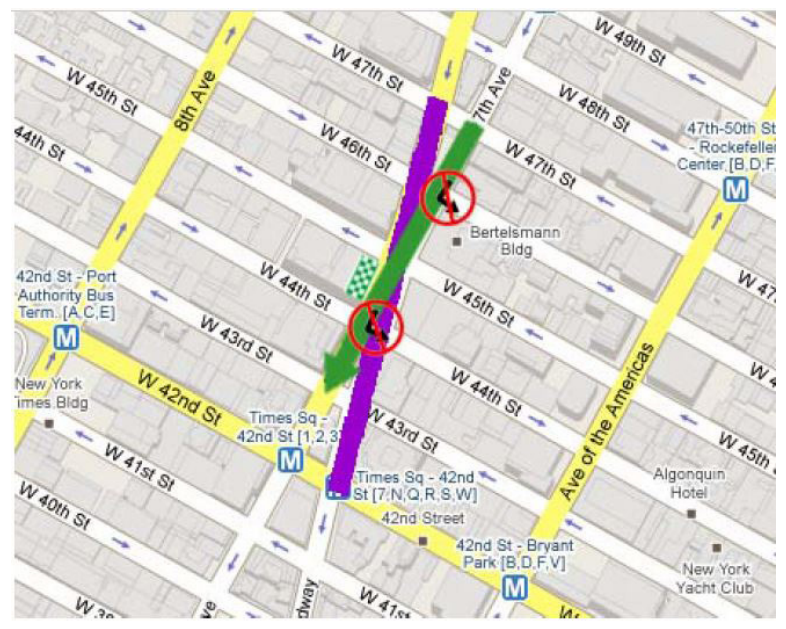

\section{Times Square}

Traffic continues down 7th Ave.

No thru-traffic Broadway 47-42nd St. Source: http://www.nyc.gov/html/dot/downloads/pdf/ from 2007 to 2030, adopting complete-street design for redevelopments, and launching a Main Street Initiative that prioritize people friendly boulevards. Policy direction in Sustainable Streets were followed up by Actions, linking clear and measurable actions to policy goals. For example, in order to achieve Mobility Policy goals of doubling the number of bicycle commuters by 2015 from 2007, Mobility Actions state that the City will install 200 new bicycle lane-miles, and install 15 additional miles of protected on-street cycling lanes. And the Strategic Plans' (2008) World Class Streets Policies aimed to expand the City's network of public spaces, leveraging its most available, streets. With transit riders, pedestrians and cyclists in mind the World Class Streets Policy includes actions on infrastructure such as improving existing plazas or transforming streets into plazas as well as community level programming like art, street murals and neighbourhood beautification initiatives. Actions were directed through pedestrian-oriented street policy such as partnering with City agencies to make public life/streetscape improve- 
Figure 4: Times Square Before and After Revitalization

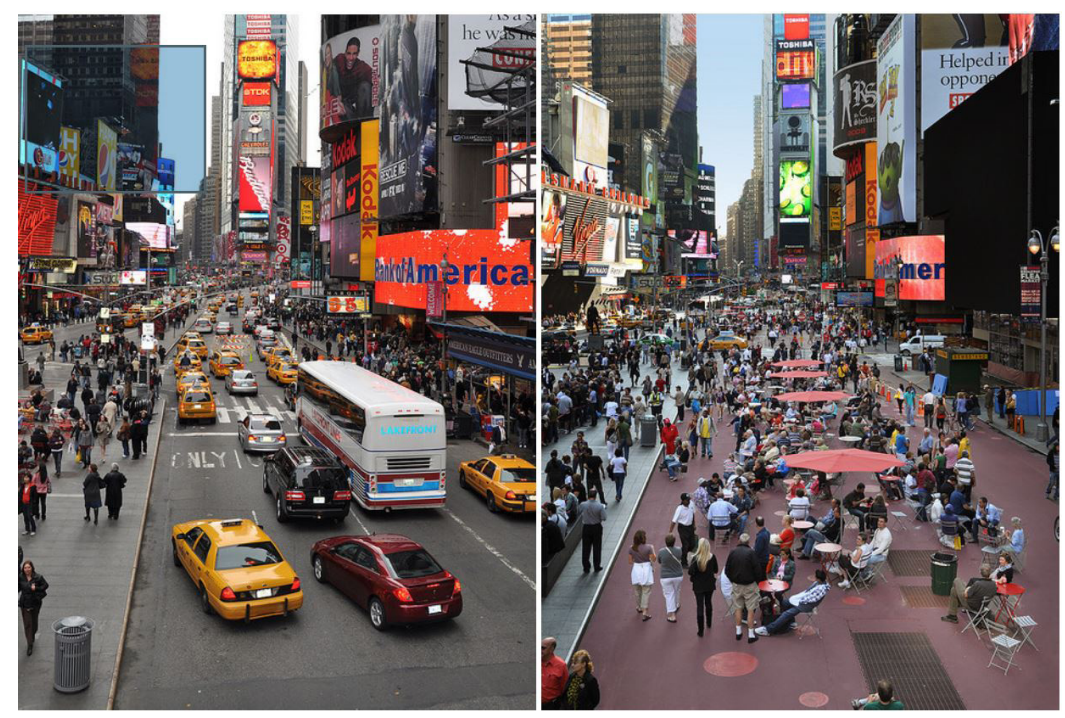

Source: http://research.gsd.harvard.edu/tut/files/2016/02/NYC-Case-121-161.pdfgreenlight_tlc.pdfbroadway_report_final ments and identifying locations for placemaking and safety improvements. The Strategic Plan catalyzed the efforts to transform New York City's streets through a broad transportation policy document and aimed to improve mobility of all users with a safety-first approach. Green Light for Midtown, was one of many

projects - including Safe Routes to School and Safe Streets for Seniors - that evolved from the policy direction in Sustainable Streets (2008). Informed by the Times Square Alliance Report (2008), and guided by policy set out in PlaNYC (2007) and Sustainable Streets (2008) the Department of Transportation launched the pilot program Greenlight for Midtown, and initiated the first phase of a long-term transformation effort. The project area extended along Broadway from South Central Park to 42nd and 35th to 46th street. Central to the project was banning cars on Broadway between 47th and 42nd (See Figure 3) streets and 35th to 33rd Streets.

\section{Evaluation of Times Square as a Great Street - Pre-Revitalization}

This chapter will apply a Great Streets evaluative framework to Times Square before and after its revitalization to examine the degree to which Times Square meets Jacobs (1993) eight Requirements and five Criteria as a Great Street. The framework will help identify the relationship between achieving the eight Requirements and 
the functioning as a Great Street. Each of the eight Requirements will be assessed along a qualitative scale.

\section{Evaluation of the Eight Requirements}

(1) Places for People to Walk with Some Leisure:

As mentioned earlier, the conditions for walking prior to the revitalization were quite poor. The street width ranged from 21 metres -31 metres while sidewalk widths ranged from 4 metres -6 metres. In total, $90 \%$ of the rights-of-ways was dedicated to vehicles leaving only $10 \%$ of the area for pedestrians (Gehl, 2008). Limited pedestrian-only space coupled with the fact that $90 \%$ of users in Times Square are pedestrians (Gehl People, n.d.) contributed to an unsafe street for those on foot with the high percentage of people struck by vehicles underscoring this problem. In summary, Requirement One was not achieved.

\section{(2) Physical Comfort}

There were little-to-no planters or trees in Times Square, thus limiting favourable micro climates like cover from rain fall or providing shade in hot sunny days. The lack of urban vegetation is contrasted by the overwhelming presence of asphalt. The heavy vehicle traffic produced poor air quality and soundscape (Lang \& Marshall, 2016). Being Encapsulated by tall towers, Times Square only receives sun light during afternoon while wind tunnel effects produce an uncomfortable setting during the winter months (2016). Based on the analysis Requirement Two was not achieved. 
Figure 5: Broadway: Before Revitalization

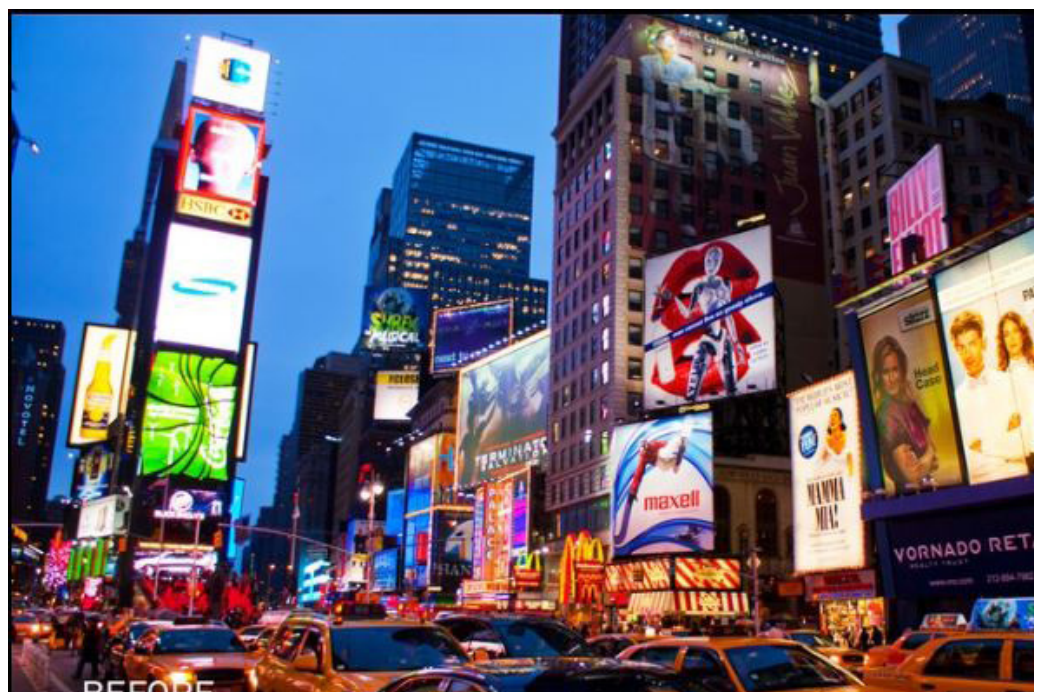

Source: https://www.archdaily.com/

Figure 6: Broadway: After Revitalization

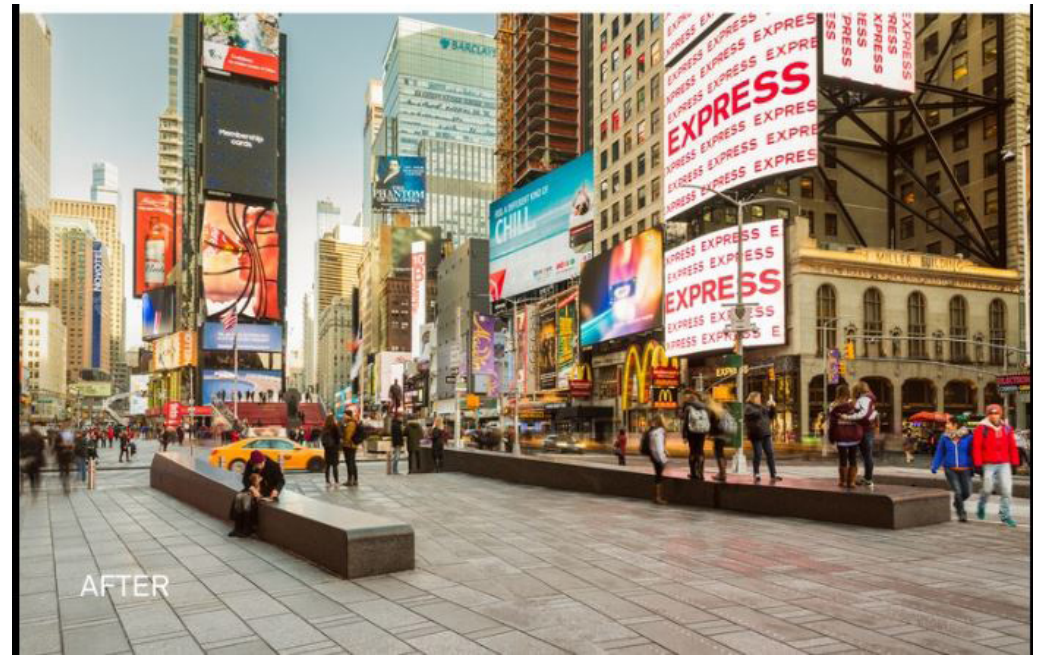

Source: https://www.archdaily.com/

(3) Definition

Much like most of Midtown Manhattan, high rise buildings are sited in and around Times Square particularly along the major corridors, Broadway and 7th Ave. Using mangomap. com heights of buildings located on Broadway and 7th Ave between 47th and 42nd St 
were noted. The average building height was calculated to be 80 metres (roughly 27 storeys). The ROW width in Times Square ranges between 21-31 metres. On the low end the building height to street width ratio is $4: 1$. On the high end the building height to street width ratio is 8:3. Both ratios exceed Jacobs (1993) Requirement of a building to height to street width ratio of 1:2. Along the base of buildings enormous billboards are relatively placed at an equal height, creating a consistent street wall contributing a sense of enclosure to the area. To summarize, Times Square can be described as exhibiting a building-to-street width ratio that exceeds the Requirement suggested by Jacobs (1993). That said, this discrepancy is balanced with a consistent street wall of advertisements along the tower base, helping frame the public realm, therefore Definition was somewhat achieved.

\section{(4) Qualities that Engage the Eye}

What's overwhelmingly apparent in Times Square is the sheer number of people cars moving throughout the area. Traffic congestion, although an inconvenience for commuters, moves a pace that is according to Jacobs (1993) conducive to what is deemed not shocking or alerting to the brain and contributes to a Great Street. The slow moving traffic sets the pace for the area, one that is more comfortable for those on foot. The movement of bright light radiating from oversized billboard advertisements and signs, particularly in the evening, contributes to the visual interest and appeal of Times Square. Requirement Four was achieved very well.

\section{(5) Transparency}

Clothing stores and restaurants with some theatres are the primary shops in the area with most orienting towards the street on both sides. Retail stores were highly transparent as many had large display windows and bright lights illuminating from within, thus making the ground floor uses more visible from the sidewalk. The majority of buildings 
are sited right to the property line. Multiple store fronts along the blocks in Times Square create an interesting rhythm and an inviting street as compared to, for example, a blank continuous street wall. Transparency was achieved very well.

\section{(6) Complementarity}

Skyscrapers provide for a consistent character in the background while the wall of billboards are noticeably placed lower making them legible at the street level. And for the majority of buildings they are consistently sited to the property line. Requirement Six was achieved very well.

\section{(7) Maintenance}

Maintenance of the area was difficult to gauge. Google street view images from 2007 are of grainy and too low quality to accurately assess the condition of the street. But based on what can be observed, there wasn't significant maintenance issues in Times Square. But A report from the Times Square Alliance (2008), did highlight some concerns with the overall cleanliness of Times Square and the condition of street furniture but this was not elaborated upon in detail. Given what was observed in Google street view and reported from Times Square Alliance (2008), the assessment for Maintenance was inconclusive.

\section{(8) Quality Design}

The street did not convey distinct or quality treatment. Rather the street condition appeared to be just asphalt pavement. Similarly public realm elements such as benches and street lights were of also generic design. The lack of design treatment is affirmed in the Times Square Alliance report (2008) notes that "the streetscape is unattractive at best" (p.2). Given this, Quality Design was not achieved. 
Figure 7: Two-toned pavers with reflective silver nickels

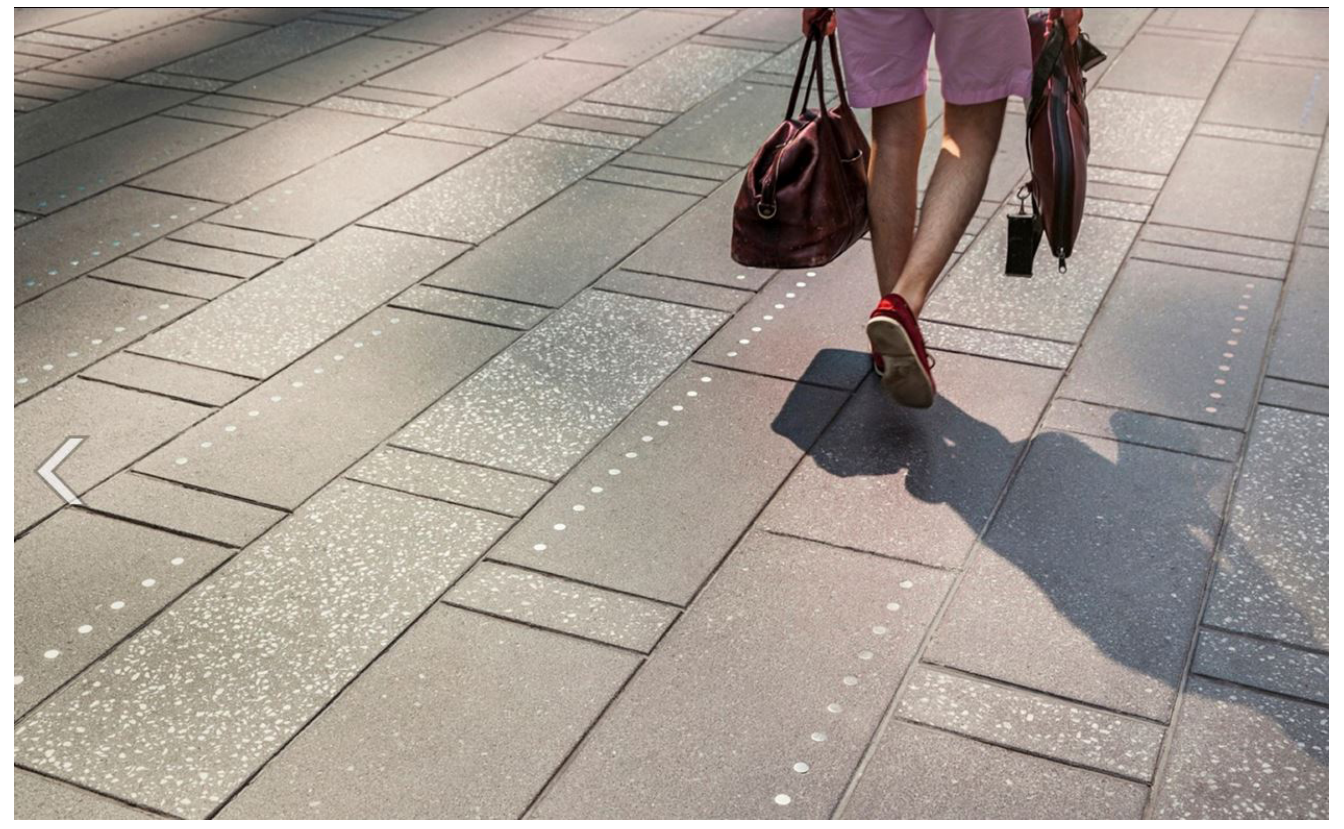

Source: https://www.archdaily.com/

The following table summarizes the qualitative assessment of the eight Requirements:

Table 2: Qualitative Assessment of the Eight Requirements of Times Square

\begin{tabular}{|l|l|}
\hline Requirement & Qualitative Assessment \\
\hline $\begin{array}{l}\text { Places for People to Walk with Some } \\
\text { Leisure }\end{array}$ & Not achieved \\
\hline Physical Comfort & Not achieved \\
\hline Definition & Somewhat achieved \\
\hline Qualities that Engage the Eye & Achieved very well \\
\hline Transparency & Achieved very well \\
\hline Complementarity & Achieved very well \\
\hline Maintenance & Inconclusive \\
\hline Quality Design & Not achieved \\
\hline
\end{tabular}

Recap

In summary, based on the observation, Times Square met four out of the eight Requirements for Great Streets. Qualities that Engage the Eye, Transparency, and 
Complementarity were found to be 'Achieved very well' while Definition was 'Somewhat achieved'. On the other hand, Requirements for Places for People to Walk with Some Leisure, Physical Comfort and Quality Design were 'Not achieved'. The assessment found Maintenance to be inconclusive because of limitations of Google Street View and lack of data. With the eight Requirements assessed, the following section of the paper will discuss to what degree Times Square met the five Criteria for Great Streets.

\section{Evaluation of the Five Criteria}

\section{(1) Foster Community}

Times Square was undoubtedly a highly visited and well known area with the highest pedestrian count in the City (Times Square Alliance, 2008) attracting over 500,000 visitors a day (Lang \& Marshall, 2016). Though there was a lack of pedestrian space it would be incorrect to state that Times Square didn't foster community. Times Square by the mid-2000s, was a major node in New York, a destination to see people from all walks of life therefore this Criteria was somewhat achieved.

\section{(2) Be Physically Comfortable and Safe}

Pedestrian safety from vehicles was a significant issue and concern in Times Square. The high pedestrian to vehicle accident rates signify the risk posed those on foot which. Limited sidewalk space and increasing pedestrian congestion contributed to a public safety hazard in the area. Criteria Two was not achieved.

\section{(3) Encourage Participation}

Formal events regularly took place with enough space to accommodate over 500, 000 people (Lang \& Marshall, 2016). The most celebrated and likely well-known is the New Year's Eve celebration occurring on New Year's Eve. Buskers and other performers could also be found in Times Square on any given day. Criteria Three was somewhat 
achieved.

(4) Be Memorable

Times Square was major tourist hub attracting visitors from all over the world. With its congestion of vehicles, high concentration of people from different walks of life, and the spectacle of billboards and lights, Times Square was a chaotic yet vibrant place. Criteria Four was achieved very well.

(5) Representative

In many ways Times Square is a unique case to examine. Before the pedestrianization of Times Square, it already had a storied history, making the name synonymous with New York. Much like the Empire State Building, Statue of Liberty and the Brooklyn Bridge, Times Square is embedded in the public image of New York through both good times and bad. From the 1960s through the early 1990s, New York's struggle through crime, poverty, and drug addiction took public stage in Times Square. Its resurgent in the 2000 s as a successful public space - attracting millions of tourists each year indicated the resurgent of New York as a whole. Criteria Five was achieved very well.

The following table summarizes the five Criteria based on the qualitative assessment:

Table 3: Qualitative Assessment of the Five Criteria of Times Square

\begin{tabular}{|l|l|}
\hline Requirement & Qualitative Assessment \\
\hline Foster Community & Somewhat achieved \\
\hline Physically Comfortable and Safe & Not achieved \\
\hline Encourage Participation & Somewhat achieved \\
\hline Be Memorable & Achieved very well \\
\hline Representative & Achieved very well \\
\hline
\end{tabular}

Recap 
Overall, Times Square achieved four out of the five Criteria for Great Streets. The analysis found that Times Square was Memorable and Representative, both being 'Achieved very well' while Foster Community and Encouraging Participation was 'Somewhat achieved'. The analysis found Times Square not to be Physically Comfortable and Safe. The results uncovered here perhaps speaks to the deficiency in three out of the eight Requirements mentioned earlier, Places to Walk with Some Leisure, Physical Comfort and Quality Design but more so for Places to Walk. Times Square was a popular destination but aside from formal events taking placing, the lack of pedestrian space diminished opportunities for people to enjoy Times Square safely and for long durations. But what Times Square seems to lack in, is made up for in it's memorable nature. There didn't seem to be special attention to the physical quality or design of the square but the display of massive advertisements and large tv screens is unlike anywhere else in the world. Secondly, Times Square benefits from being a prominent New York symbol. Times Square fell short in achieving all eight physical Requirements and all five Criteria for Great Streets but it was a successful public space. It was a Great street but it needed improvements to make it even Greater.

\section{Evaluation of Times Square Post Revitalization}

With the pre-revitalization assessment of Times Square as a Great Street discussed earlier, this section will apply the same evaluation post revitalization and assess the degree to which the redesigns meet the eight Requirement and five Criteria for Great Streets.

Evaluation of the Eight Requirements

(1) Places for People to Walk with Some Leisure: 
Initially closed off by traffic cones, lawn chairs and tables, the transition to a fully permanent redesign of 5 city blocks, created 140, 000 sf of new pedestrian space evident in a new plaza and widened sidewalks. Several 50 - foot long granite seating are now present in Times Square within the new pedestrian plaza area (Minutillo, 2017; Colvin, 2011; Owen, 2013). The benches provide for much needed seating in the Square and are placed in a manner that helps direct the North-South flow of people (Auckland Design Manual, n.d.). In addition to closing off Broadway to vehicles and widening sidewalks space, pedestrian improvements were also evident in improved traffic signals to allow for more time to cross streets, contributing to a less frenetic pace for users in the space. Significant changes were made to Times Square that greatly increased for walking and leisure. Requirement One is achieved very well.

\section{(2) Physical Comfort}

The removal of traffic lanes on Broadway from 47th to 42nd St appear to have help with improving the air quality in Times Square evident in the 60\% drop in air pollution (Minutillo, 2017). Stainless steel pucks embedded in the new plaza's charcoal precast pavers reflect light from building signs contribute to Squares overall visibility during the evening. Little-to-no trees were introduced in the area, which could have provided shade, or wind protection. With regards to lack of sun light during the day and channeling of wind due to the height and enclosing nature of tall buildings, it is assumed that no improvements have been made. At the same time such changes are beyond the scope of the revitalization of Times Square. Taken together, physical comfort is somewhat achieved.

\section{(3) Definition}

The definition of the plaza is accentuated by charcoal pavement and steel discs of the pedestrian plaza. In regards to building height-to-street width ratio, the ROW within 
Times Square is assumed to have been unchanged. Similarly it appears that the street wall rhythm of large advertisements remains consistent with the characteristic prior to the permanent changes in Times Square. Definition is somewhat achieved.

\section{(4) Qualities that Engage the Eye}

Before the redesign by Snohetta, Times Square was already visually appealing due to the movement of a great number of people, cars, along with the scale and intensity of advertisements and illuminating light. But the permanent design included the charcoal pavement with embedded silver discs. The silver discs accentuate the visual interest and experience during the evening as they act as reflectors to the bright lights emitted off buildings and advertisements (Owen, 2013; Colvin, 2017). As such, the Requirement is achieved very well.

\section{(5) Transparency}

The stores have changed, somewhat, since 2007 but the building orientation and overall treatment of windows is consistent with the high transparency before revitalization. That said, the Requirement Five is achieved very well.

\section{(6) Complementarity}

As mentioned earlier, there have been some changes in retail storefronts but there remains consistent building character in Times Square. The Requirement is achieved very well.

\section{(7) Maintenance}

Maintenance of the area was is difficult to gauge. The brand-new pedestrian plaza is less than 2 years old and observation through Google Earth does not indicate an unmaintained area. Older public realm elements were removed such as traffic lights at the end of their life span and old phone booths. The assessment of Requirement Seven 
is inconclusive.

(8) Quality Design

The detail in the charcoal pavers and the decision for selecting them is evidence of careful consideration and design detail. The dark-toned pavers (Figure 7) were chosen because the intent was to balance the illuminating quality of Times Square during the evening. Whereas the dark-toned pavers complement the brightness of Times Square, the silver discs embedded in the pavers help reinforce the 'bright lights' aesthetic of the area. The design of the 50-foot granite benches were carefully considered in terms of multifunctionality. This meant providing people opportunities for multiple resting positions other than sitting. Requirement Eight was achieved very well.

The following table (Table 4) compares and contrasts the eight Requirements of Times Square before and after revitalization while also noting any changes.

Table 4: The Eight Requirements of Times Square Before Revitalization and After Revitalization:

\begin{tabular}{|l|l|l|l|}
\hline Requirement & $\begin{array}{l}\text { Qualitative } \\
\text { Assessment } \\
\text { Before } \\
\text { Revitalization }\end{array}$ & $\begin{array}{l}\text { Qualitative } \\
\text { Assessment After } \\
\text { Revitalization }\end{array}$ & $\begin{array}{l}\text { Change in } \\
\text { Requirement }\end{array}$ \\
\hline $\begin{array}{l}\text { Places for People } \\
\text { to Walk with Some } \\
\text { Leisure }\end{array}$ & Not achieved & Achieved very well & Improved \\
\hline Physical Comfort & Not achieved & Somewhat achieved & Improved \\
\hline Definition & Somewhat achieved & Somewhat achieved & No change \\
\hline $\begin{array}{l}\text { Qualities that } \\
\text { Engage the Eye }\end{array}$ & Achieved very well & Achieved very well & No change \\
\hline Transparency & Achieved very well & Achieved very well & No change \\
\hline Complementarity & Achieved very well & Achieved very well & No change \\
\hline Maintenance & Inconclusive & Inconclusive & No change \\
\hline Quality Design & Not achieved & Achieved very well & Improved \\
\hline
\end{tabular}

Recap 
Compared to the character prior to revitalization the permanent redesign of Times Square, made noticeable improvements to three Requirements. As a result of the revitalization Places for People to Walk and Quality Design were significantly improved and physical comfort was somewhat improved upon. Evident of the changes include the additional 140, $000 \mathrm{sf}$ of new pedestrian space, permanent seating, and quality paver treatment to the plaza. The next section will discuss the results of the changes in physical Requirements in relation to changes in the five Criteria.

\section{Evaluation of the Five Criteria}

\section{(1) Foster Community}

Five blocks of pedestrian plaza provide a node of activity, creating a central gathering space in the middle of Times Square. Importantly, people are now have the ability to stop, pause, and enjoy the Square without worry of oncoming vehicles. Both formal and informal activities in the Square continue to occur while workers in the area are more inclined to visit during lunch hours (Osuldsen, 2017). Criteria One was achieved very well.

\section{(2) Physically Comfortable and Safe}

There has been marked improvements to the physical comfort and safety to pedestrians since the changes to Times Square. Data affirm the positive changes to public safety - both real and perceived - for the area. For example there was a $35 \%$ decrease in pedestrian injuries soon after the Broadway was closed to vehicles (City of New York Department of Transportation, n.d.) and a 40\% reduction between 2016 and 2017 (Katz, 2017). In terms of safety, $80 \%$ of visitors say that the new pedestrian plaza makes them feel safer (Katz, 2017). Criteria Two is achieved very well. 
Encourage Participation

More people are spending time in Times Square and are staying for longer durations.

$84 \%$ more people now read, eat, and take photographs in the area (Osuldsen, 2017)

with average population of stationary people in Times Square has increasing from 17 to 90 since the changes (City of New York, 2013). Encouraging people to stay is furthered by the events and programming that occur in the Square and this includes public art projects, political demonstrations, food kiosks, and outdoor yoga classes (Minutillo, 2017). Furthermore outlets installed in the granite benches are intended to serve different event programming throughout the year (2017). Criteria Three is achieved very well.

\section{(4) Be Memorable}

Being able to comfortably sit in the middle of Times Square, an area that use to be for vehicles likely improves the experience for visitors. Coupled with the magnitude of revitalization and where it took place, it assumed that Times Square would have a lasting impression upon users. Evident of this is the result that $93 \%$ of visitors agree that the pedestrian plaza makes Times Square a pleasant place to be (Snohetta designs 2.5 acres, 2017). It was also found that $57 \%$ of visitors to the area shared their Times Square visit on social media (Osuldsen, 2017). And 88\% of New Yorkers agree that the plaza provides a unique atmosphere that was not there before (Snohetta designs 2.5 acres, 2017).

(5) Be Representative.

Times Square continues to be a mirror of New York City as-a-whole and the permanent redesign reflects the current values and priorities of the City. Prior to revitalization Times Square indicated an economic resurgent of New York. Today, Times Square signifies a shift towards progressive city policies that prioritize public space and the safety and 
experience of people. Criteria Five is achieved very well.

The following table (Table 5) compares and contrasts the five Criteria of Times Square before and after revitalization while also noting any changes.

Table 5: The Five Criteria of Times Square Before Revitalization and After Revitalization

\begin{tabular}{|l|l|l|l|}
\hline Criteria & $\begin{array}{l}\text { Qualitative } \\
\text { Assessment } \\
\text { Before } \\
\text { Revitalization }\end{array}$ & $\begin{array}{l}\text { Qualitative } \\
\text { Assessment After } \\
\text { Revitalization }\end{array}$ & Change in Criteria \\
\hline Foster Community & Somewhat achieved & Achieved very well & Improved \\
\hline $\begin{array}{l}\text { Physically } \\
\text { Comfortable and } \\
\text { Safe }\end{array}$ & Not achieved & Achieved very well & Improved \\
\hline $\begin{array}{l}\text { Encourage } \\
\text { Participation }\end{array}$ & Somewhat achieved & Achieved very well & Improved \\
\hline Be Memorable & Achieved very well & Achieved very well & No change \\
\hline Representative & Achieved very well & Achieved very well & No change \\
\hline
\end{tabular}

Recap

Analysis of the five Criteria post revitalization exhibit improvements to the following:

Foster Community, Physically Comfortable and Safe, and Encourage Participation.

The two remaining Criteria, Be Memorable and Representative, though noted as having 'no change' since revitalization, it should be noted that change to the character of Times Square has changed. In other words, Times Square remains memorable and representative but in a different manner.

\section{Analysis and Conclusion}

Using an evaluative framework of Great Streets, a two step analysis was applied to Times Square prior to and post revitalization. The first step involved using a qualitative scale to assess the degree to which Times Square met the eight 
Requirement for Great Streets. Secondly, using the same qualitative scale Times Square was examined based on the five Criteria.

Based on the analysis five out of the eight Requirements and three out of the five Criteria were met in Times Square prior to revitalization. It was found that Times Square functioned as Great Street but a significant reason for this can be attributed to established to its noted reputation and being synonymous with the City of New York. The permanent redesign of Times Square resulted in changes that drastically improved areas for walking and leisure, comfort as well as design. The magnitude of change altered the function of Times Square by creating more public space for people on foot to enjoy. The transformation of vehicle lanes into pedestrian only space is at the heart of the changes and allowed Times Square to improve across the five Criteria. Quality Design through paver treatment and placement of permanent benches reinforced the comfort and safety of the Times Square and represented the City's regard for public space in New York.

In short, the analysis above highlights functional improvements as-a-result of physical improvements. Times Square, though already a Great Street prior to revitalization became an even Greater street because design changes. By prioritizing the experience of those on foot the City of New York took bold action in closing 5 blocks of a major vehicle thoroughfare. The pedestrianization of Times Square and closing of Broadway Ave. From 47th street to 42 street was critical for any success to unfold. The permanent redesign of the area appears to indicate not only a successful project but a Great Street as pedestrian-safety conflict has decreased, public opinion polls appear to be overwhelmingly in favor of the new design and pedestrians are now comfortably staying in Times Square. Importantly the pedestrianization of Times Square was a statement of city building, one that prioritize public space and the importance of pedestrian experiences. 


\section{CHAPTER FIVE: YONGE AS A GREAT STREET}

\section{Preamble}

Much like New York City during early and mid-2000s, Yonge St and much of Downtown Toronto is undergoing significant changes due to rapid development in residential condos along with growth in student population and employment in the area (Downtown Yonge BIA, 2015). The intensification of a growing population will put considerable pressure on the existing infrastructure along Yonge including its public spaces. Downtown Yonge today draws in daily crowds of over 580,000 people (2015). As was the case in Times Square, limited sidewalk space and overcrowding create safety concerns from oncoming vehicle traffic (2015). The challenges ahead for Yonge St parallels the challenges of Times Square in the mid-2000s therefore it is relevant and beneficial to synthesize the challenges and opportunities between the two cases. The revitalization of Times Square aimed to improve pedestrian safety by and experience by transforming its streets. And the calls for the transformation of Yonge follow a similar argument. With an rapidly intensifying population in and around Yonge, how can Yonge not only accommodate future demands on its public spaces but do so in a manner that improves quality of life?

\section{History of Yonge Street}

Considered to be Toronto's 'main street' (City of Toronto, n.d.) Yonge Street is a major north-south arterial road that extends across 10 different cities and towns. Before the arrival of European settlers, Yonge Street functioned as First Nation Trail (Magel, 1998). With the introduction of the large department store in 1869 Yonge functioned as Toronto's major retail street (KPMG and Greenburg Consultants, 2011). In the 
late 1960s, the Eaton Centre was proposed to be developed at Yonge and Dundas triggered land values to jump, influencing small business owners to sell their property (Orzeck, 2002). The new Eaton Centre, oriented its' shops inwards, and deprived

Figure 8: Massage Parlours on Yonge St (undated)

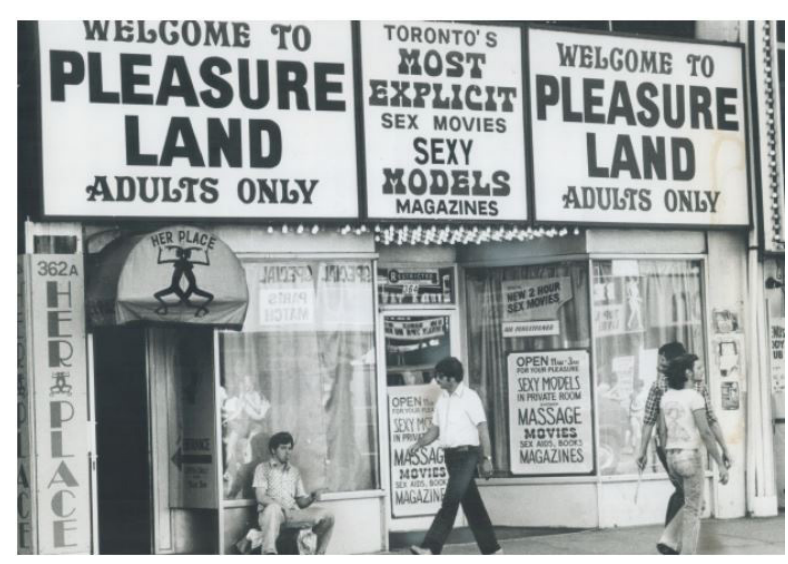

Source: 5http://www.cbc.ca/news/canada/toronto/ emanuel-jaques-yonge-street-sex-work-1.4172511 the street of public activity. This along with the seemingly sudden availability of retail space seem to have created the opportunity for to Yonge to drift down a seedier environment. Several adult related stores - strip clubs, massage parlous, and adult $\mathrm{x}$ - rated movie theatres (Figure 8) - became the norm and Yonge St then became known as the 'Sin Strip' (Fraser, 2017). Public concern and demand for change to Yonge was

common but it was the murder of 12-year-old shoe shine boy Emanuel Jaques in the Summer of 1977 that ignited a city-wide call to drive out the sex industry on Yonge St (2017). It was not the first nor the last. For over 40 years between the 1960s and early 2000s, there were several calls to revitalize this portion of Yonge St (Orzeck, 2002). By 1998, Yonge at Dundas was viewed as an area "ragged with decay, left by the city and by big businesses to fend for itself' (Yum, 1998). Developed in 1995 the Yonge Street Business and Residents Association initiated a campaign in partnership with the City of Toronto to create Canada's Time Square (Yum, 1998). With 1 million people visiting the area each week the area also had a reputation as being a dangerous with the highest incidences of crime in the city (1998). 
Figure 9: Yonge looking north from Queen (between 19781983)

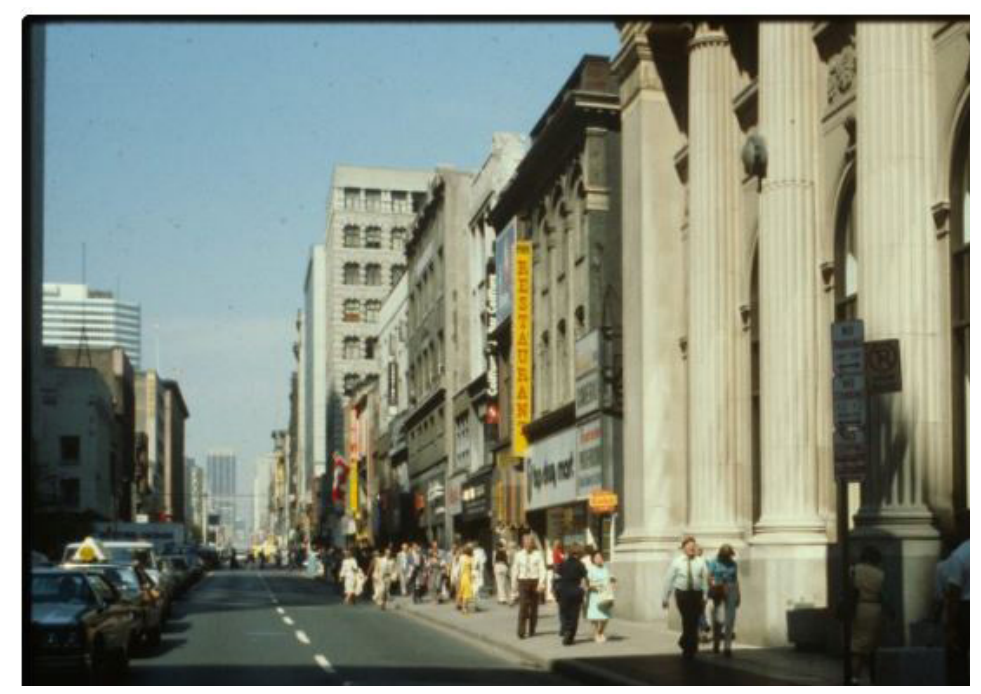

Source: https://www.toronto.ca/

\section{Yonge St Today: Site Context}

\section{Even when Yonge St}

was a strip lined with body

rub parlours and strip clubs, it functioned as the centre of urban life for Torontonians (Ross, 2017). The heart of Yonge Street is located between Queen Street to the south and College/Carlton Street to the north is one of the

if not most pedestrian foot traffic heavy space in the City (City of Toronto Staff Report, 2012). The Downtown Yonge neighbourhood is growing rapidly with a $40 \%$ growth rate projected between 2009-2025 (City of Toronto Staff Report, 2017) and is undergoing unprecedented development with current proposals for some of the most significant projects in the City. Pressures on existing basic infrastructure and in particular transportation have caused some to say that Yonge St is at a 'crisis point' (Kettel, 2016). Three major subway stations - Queen Station, Dundas Station, and College Station - are located along Yonge providing access to the core parts of downtown bringing in 600,000 workers/day (Staff Report, 2017). Several significant sites are located in the Downtown Yonge area including the Financial District, Eaton Centre, Yonge-Dundas Square, and Ryerson University. Ryerson University alone is home to 43,000 part time and full time students (Ryerson University, n.d.) while the Eaton Centre attracts nearly 50 million visitors annually (Cadillac Fairview, n.d.) 
Figure 10 Yonge St Development Applications

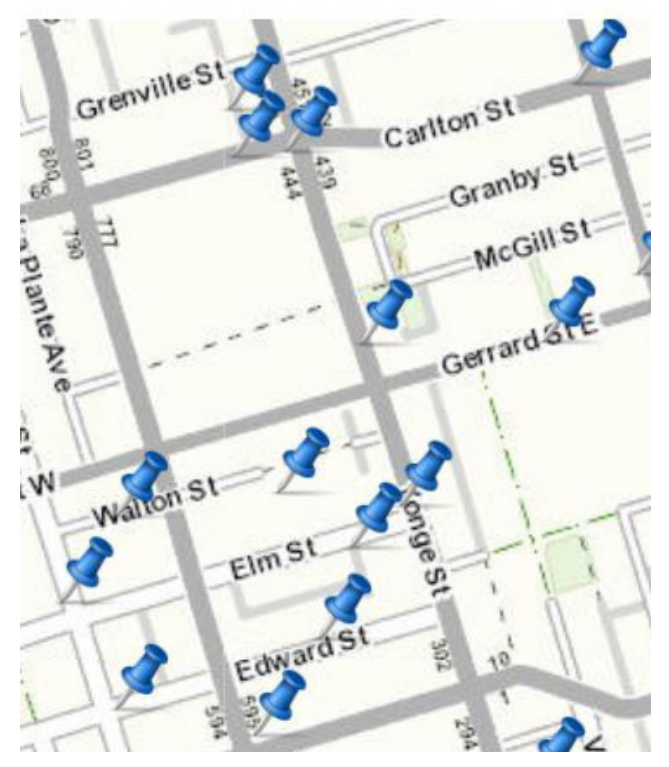

Source: https://www.toronto.ca/
The study area is designated predominantly as a mixed use area according to Map 18, Land Use of the Official Plan. Comprised of mostly low-scale built form, Yonge St functions as a commercial retail area with restaurants and entertainment. As of today, there are 20 development applications (Figure 10) in the area bounded by College St, Church St, Queen St and Bay St. While the Official Plan attempts to guide growth in a manner that fits within the surrounding context and respects human scale, proposed developments for this area are of a magnitude that was not anticipated (City of Toronto Staff Report, 2017).

The more notable proposals - 363 Yonge (at Gerrard), a 98-storey mixed use tower and 469 Elm St, an 80-storey mixed residential and office tower - signify the trend towards a more vertical community along Yonge St, a shift away from the current low-scale built form character of the area.

\section{Policy Context - To Core}

In recent years the City of Toronto has explicitly set out to improve and expand the City's open space and public realm. Several policies and guidelines exists that help direct the development and revitalization of public spaces but most relevant to this study are the recent Draft Downtown Secondary Plan, ToCore (2017) and the Complete Streets Guidelines (2016). The 25-year Draft Downtown Secondary Plan, TOCore identifies parks and public realm as 1 of 5 key infrastructure-related strategies. The first 
comprehensive plan for the downtown core since 1976, TOCore attempts to balance the downtown's unprecedented growth while ensuring that it contributes to a high quality of life. TOCore emphasizes the important function of parks and the public realm by setting out a visionary framework to promoting and revitalizing Toronto's public spaces. Relevant to this paper is the identification of Yonge St as one out 12 'Great Streets'. To be clear, the use of the term 'Great Streets' is unrelated to Jacobs (1993) concept of Great Street. The Section 7 of the draft Secondary Plan defines Great Streets as having:

"a diverse character that conveys our public image to the world and sets the stage for festivals, parades and civic life. Theses streets hold cultural and historical significance, provide connections to the Core Circle, and are significant public places. They are destinations in themselves, lined with landmark buildings, historic fabric and public spaces." (p.24).

Section 7 establishes the historical and cultural significance of Yonge St, among other streets, where such traits will be prioritized for public realm improvements. Specifically, Section 7.23 states that public realm improvements will:

7.23.1 reinforce the identity and distinct characteristics of each segment of each street including specific heritage value (24);

7.23.2. be required to implement the highest standard of design and the highest quality of materials (p.24); and

7.23.3. be informed by the Toronto Complete Streets Guidelines (p.24)

\section{Complete Streets Guidelines}

In 2016, the City of Toronto released its Complete Streets Guideline, adding to a 
list of design guidelines that inform and enhance the public realm. The CSG culminated from a comprehensive study of best practices and public engagement that involved a series of public workshops, meetings, and interactive photo contests and bike tours. Recognizing the importance of streets and a need to balance different uses and users the guideline serves to help enhance overall safety and respond to local context through design. First, and foremost, safe right-of-way movement of pedestrians, cyclists and transit riders is the main priority. Three guiding principles help the CSG reinforce the goals of the Official Plan. First, Streets for People prioritizes barrier free mobility for users of all abilities. Streets for Placemaking complements the priority of movement and places emphasis on the opportunity for social activities of streets and sidewalks. Importantly, this principle takes into account local built environment and identity and encourages streets to be vibrant places for gathering. And lastly, economic vitality, equity, and flexibility are highlighted by the Streets for Prosperity principle. This principle underscores efficiency in movement of people being important to local retail.

Both ToCore and the Complete Streets Guidelines acknowledge the multiple and vital function of streets and makes explicit the City of Toronto's intention to ensure that the public realm features are protected and enhanced during redevelopments. Through Official Plan Policy they provide an important framework in exploring how Yonge St may be transformed into what ToCore defines as a Great Street.

\section{Evaluation of Yonge as a Great Street}

While there have been issues and challenges raised about Yonge St over recent years, the next section will apply the great streets evaluative framework to assess the degree to which Yonge between Queen and College meets the eight Requirements . This will provide a baseline assessment of how Yonge St performs within a Great 
St Framework. Following the evaluation, possibilities for design solutions will be recommended.

\section{Evaluation of the Eight Requirements}

(1) Places for People to Walk with Some Leisure

Figure 11 Yonge St Looking south from Gerrard

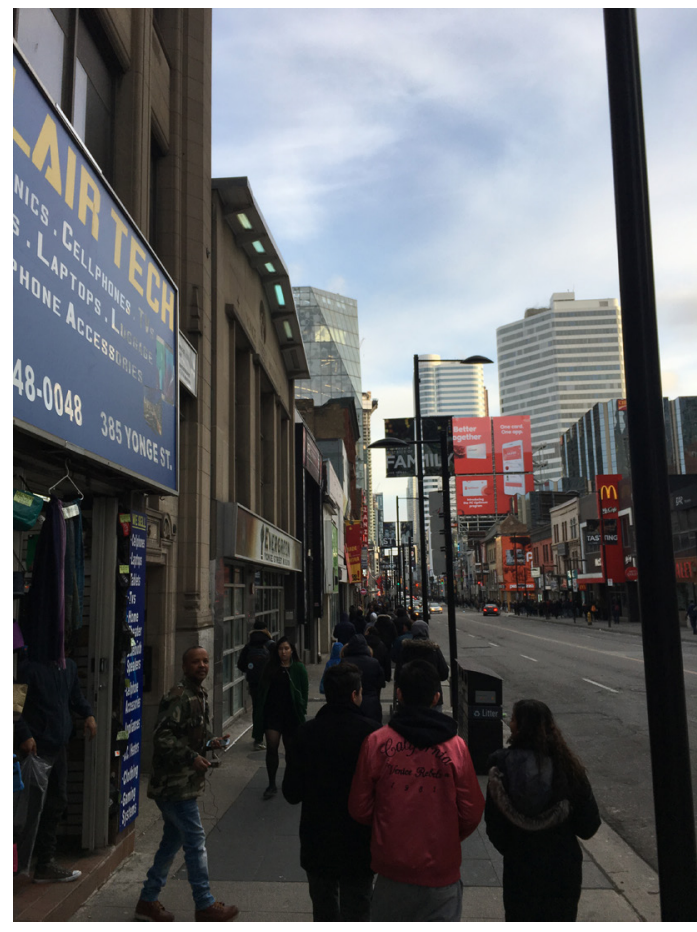

Source: John Nguyen
Using the City of Toronto Interactive Map and measuring tool, the width of sidewalks along Yonge St were on average 3.5 metres and the widths of the street ranged between 12 and 13 metres. During the warmer seasons of June 2017 to August 2017, the average of the number of pedestrians visiting the area ranges from 125,000 to 150,000 people per week (Downtown Yonge BIA, 2018). And based on January 2017 counts, the split between pedestrian and vehicle traffic was $63 \%$ to $27 \%$. Data on the amount of foot traffic relative to the amount of pedestrian sidewalk space indicate that there is limited space for pedestrians to comfortably walk while spillover on the street isn't uncommon. Several

parks and parkettes are present along the Yonge St corridor. This is includes Joseph Sheard Parkette (Granby St and Sheard St); Mcgill Parkette (Yonge St \& Gerrard St E); Ryerson Community Park (Gould St and Church St); Devonian Pond (Gould St and Church St);; Dundas Square (Yonge St and Dundas St); and Trinity Square. Dundas Square is the most prominent and highly used public space in the area with 52 million visitors annually (ydsquare, n.d.). Formal functions, outdoor concerts and celebrations are a common site here during both evening and weekend. The Ryerson's Student 
Learning Centre, is a popular gathering spot for students throughout the school year with south facing steps that open out and orient towards Yonge St. In the 1 kilometre stretch between Queen St. and College St. There is only 1 street bench sited at Yonge St and Mcgill Parkette, an indication of the small amount of space available for people to pause on the street. Given how crowding is a common occurrence on Yonge and the lack of space to stop without impeding the flow of others, it was found that the Requirement for People to Walk with Some Leisure was not met.

\section{(2) Physical Comfort}

With narrow sidewalks coupled with crowding pedestrians often walk right along the sidewalk edge, or spill over directly onto the vehicle lane. Lamp posts, garbage bins and mail boxes along the edge zone help create a buffer between cars and pedestrians but also take up limited walking space. Sidewalks west of Yonge St are generally wider than the ones on the East side, ranging between $7-10$ metres between Gerrard St and College St and 4-12 metres between Dundas St and Queen St. Streets trees are sited along each side of Yonge from Gerrard to College. But south of Gerrard - save for the few in Dundas Square - there is no street trees along Yonge. The lack of trees indicate limited opportunity for protection from the sun on hot and bright days and limited cover from rain during rainy days. Given the limited spaces for walking and lack of protection from natural elements it is concluded that Physical Comfort was not achieved.

\section{(3) Definition}

Yonge can be described as having a low and medium scale built form pattern and with an approximately 20 metre right-of-way, the street does establish a sense of enclosure. Being in the heart of downtown, Yonge St is noticeably built at a human scale. There are however, extreme exceptions to the low and medium scale form. At 78 storeys the 
Figure 12 Yonge St view corridor looking south

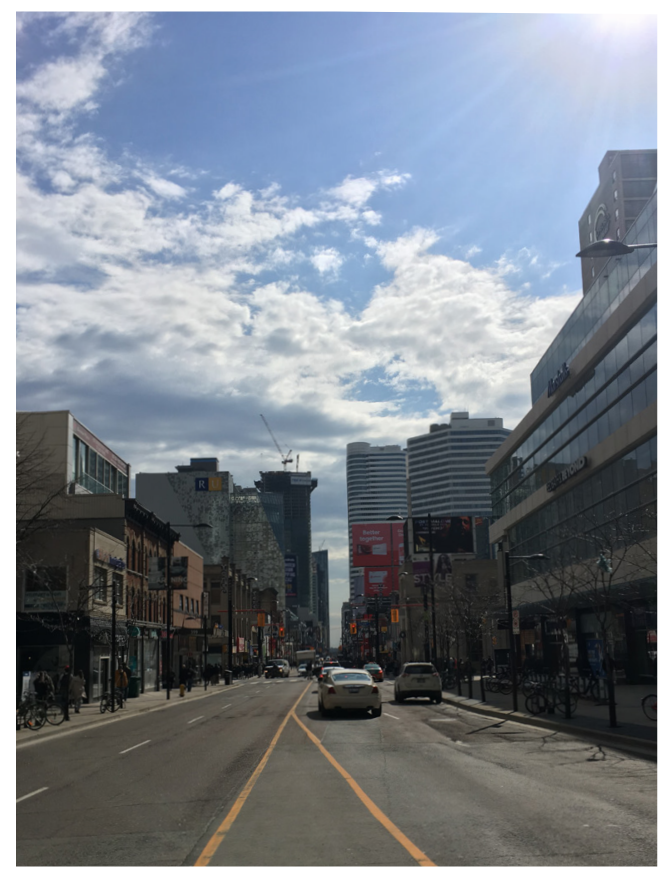

Source: John Nguyen

residential complex Aura on the east side at Gerrard is by far the tallest building on Yonge St, contrasts with the immediate buildings adjacent to it. A scan of proposed developments -415 Yonge St and 388 Yonge St - hint at a potential future where tall towers will be a norm on Yonge St. Definition was somewhat achieved.

(4) Qualities that Engage the Eye Remnants of the streets past character remain in various forms. 18 listed heritage properties are concentrated between Queen St and Dundas Sq and 13 from Dundas St to just north of Gerrard St. These buildings, built from stone and brick, not only contribute to Toronto cultural heritage, but are architecturally interesting and contribute to the overall liveliness and appeal of the city. When arriving at Yonge-Dundas Square one is encapsulated with enormous screens and digital billboards advertising wellknown brand items. The scale of advertisement, and the unexpected openness of the space and illumination from signs at night give prominence to the square. Lastly, the large concentration of people itself contributes to the visual interest of the street. This Requirement is achieved very well. 
Figure 13 Billboards and advertisements on Yonge St

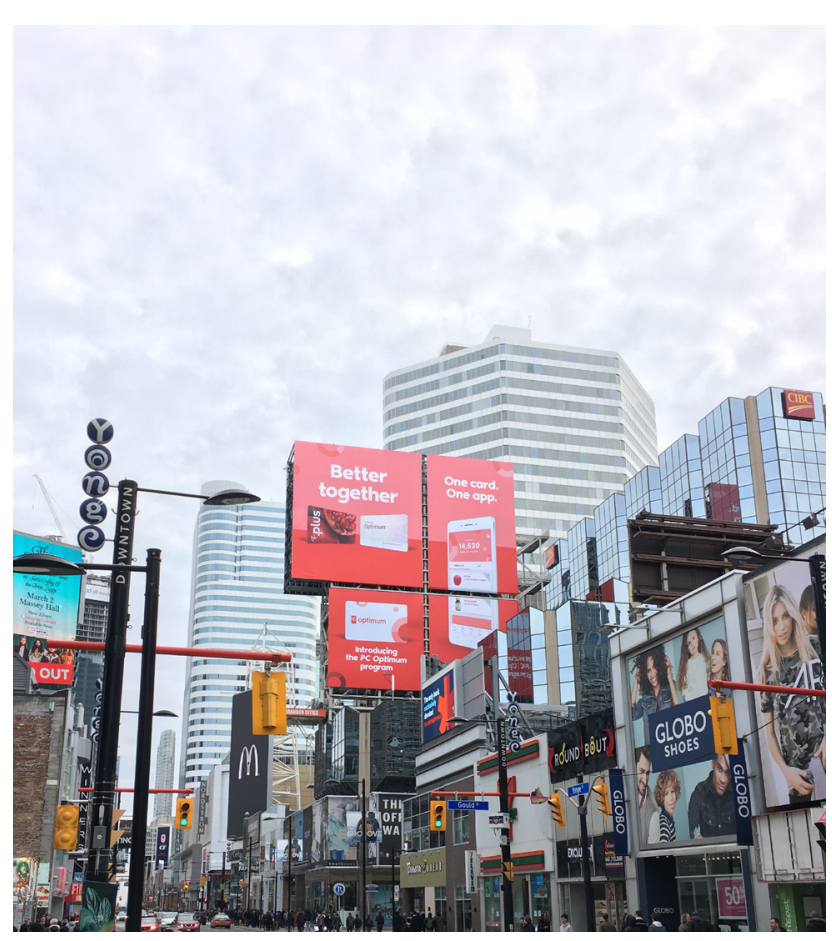

Transparency

With a diverse mix of retail on Yonge

St, there is a also a mix in building wall transparency. The level of visual connections between pedestrians on sidewalks and the activities inside buildings along the street varies. On its' west side from Queen St to Dundas St, low transparency is prominent due to the blank walls of the Eaton Centre (Figure 11). Continuing north from Dundas St, a more transparent storefront pattern is Source: John Nguyen noticeable with large windows of restaurants and clothing stores. However there is a visual disconnect between pedestrians and inside the buildings as one move further north from Gerrard St to College St; this is evident, for example, by two commercial banks sited right next to each other while large advertisement displays and empty storefronts at College Park building nearly hide the fact there are street front entrances to the shops. On the other hand, the succession of well-lit shops and restaurants with large windows create the most engaging building wall along the East side of Yonge St between Queen and Shuter St. There is an apparent imbalance in Transparency along Yonge. There are sections along Yonge with blank street walls while other portions of Yonge convey inviting storefronts with large and transparent windows, making visible the goods and services offered in-store. Given the imbalance in transparency, this Requirement is somewhat achieved. 
Figure 14 Blank building wall along the Eaton Centre

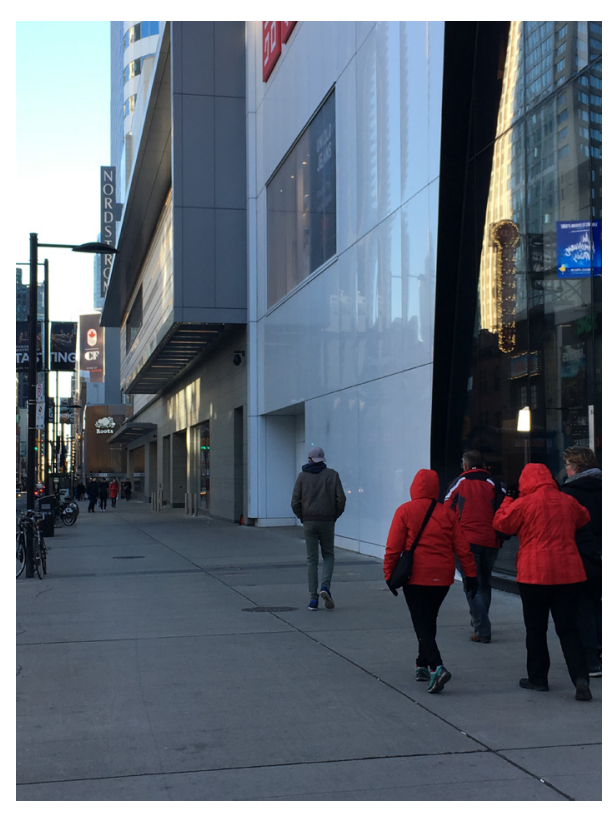

Source: John Nguyen
(6) Complementarity

The majority of building are situated right to the edge of their property line while the building characteristics in the area vary widely. Historic brick and stone buildings are featured along with newer post-war architecture designed with unrelated facades. Several distinct buildings with large footprints contrasts with the predominantly low-scale and fine-grain retail of Yonge St and together diverge from a complementary design aesthetic. Aside from its enormous billboards, the defining feature of 10 Dundas $E$ is a 10 storey gray industrial façade while the Eaton Centre takes

form as a windowless box. This requirement is somewhat achieved.

Figure 15 Yonge St looking north to College

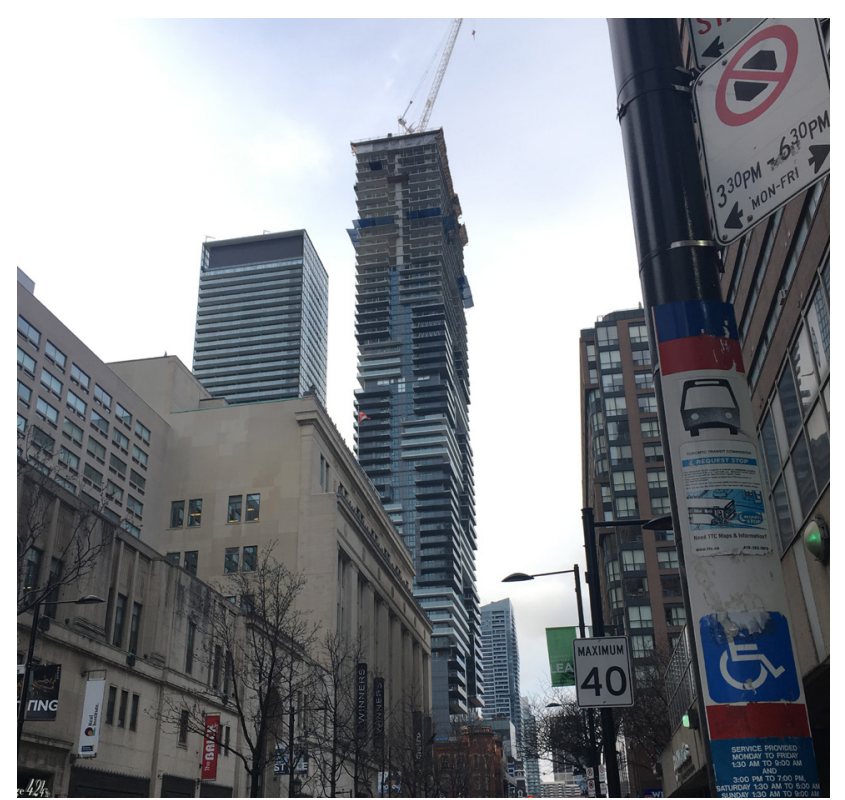

Source: John Nguyen

\section{(7) Maintenance}

Overall the street was observed to be clean with garbage bins being a consistent feature along the sidewalk. Streets trees and planters along the meridian are healthy and help provide a sense of care to Yonge St. In the evening and in particular during the weekend, litter is not an uncommon site. Requirement Seven is somewhat achieved.

(8) Quality Design 
There isn't a consistent design to Yonge. The current sidewalk and street treatment varies especially areas fronting newer buildings as compared to the older parts of Yonge. As a public space, Yonge is not designed in manner that is distinct from adjacent

Figure 16 College Park Building with the Aura in the background

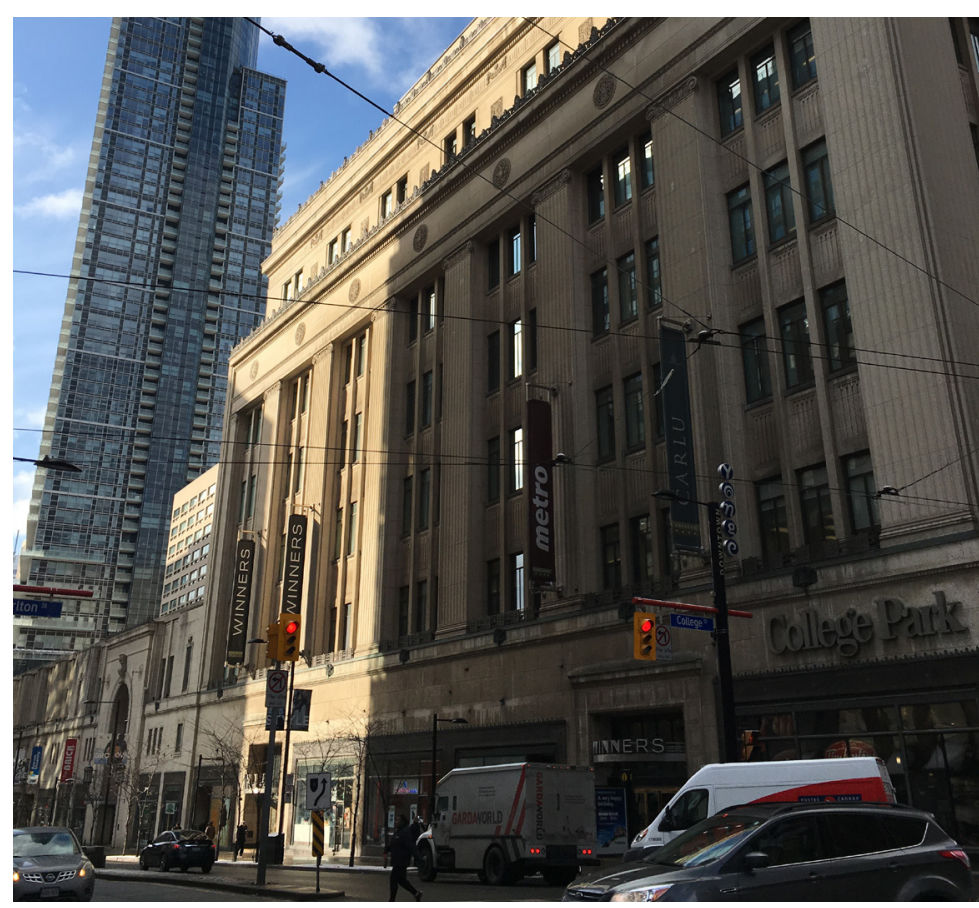

streets. In other words, aside

from street banners, there is no defining design character to Yonge that establishes it as a special area. The street looks and functions like many streets in downtown Toronto. Requirement Eight is not achieved.

The following table (Table

6) summarizes the qualitative assessment of the eight Requirement for Yonge St:

Source: John Nguyen

Table 6: Qualitative Assessment of the Eight Requirements of Yonge St

\begin{tabular}{|l|l|}
\hline Requirement & Qualitative Assessment \\
\hline $\begin{array}{l}\text { Places for People to Walk with Some } \\
\text { Leisure }\end{array}$ & Not achieved \\
\hline Physical Comfort & Not achieved \\
\hline Definition & Somewhat achieved \\
\hline Qualities that Engage the Eye & Achieved very well \\
\hline Transparency & Somewhat achieved \\
\hline Complementarity & Somewhat achieved \\
\hline Maintenance & Somewhat achieved \\
\hline Quality Design & Not achieved \\
\hline
\end{tabular}

The following table (Table 7 ) offers a comparison of the eight Requirements between Times Square before revitalization and Yonge St 
Table 7: Comparison of the Eight Requirement between Times Square (prior to revitalization) and Yonge St

\begin{tabular}{|l|l|l|}
\hline Requirement & $\begin{array}{l}\text { Times Square Qualitative } \\
\text { Assessment of the Eight } \\
\text { Requirement Before } \\
\text { Revitalization }\end{array}$ & $\begin{array}{l}\text { Yonge St Qualitative } \\
\text { Assessment of the Eight } \\
\text { Requirement }\end{array}$ \\
\hline $\begin{array}{l}\text { Places for People to Walk } \\
\text { with Some Leisure }\end{array}$ & Not achieved & Not achieved \\
\hline Physical Comfort & Not achieved & Not achieved \\
\hline Definition & Somewhat achieved & Somewhat achieved \\
\hline $\begin{array}{l}\text { Qualities that Engage the } \\
\text { Eye }\end{array}$ & Achieved very well & Achieved very well \\
\hline Transparency & Achieved very well & Somewhat achieved \\
\hline Complementarity & Achieved very well & Somewhat achieved \\
\hline Maintenance & Inconclusive & Somewhat achieved \\
\hline Quality Design & Not achieved & Not achieved \\
\hline
\end{tabular}

Recap

With the exception of Maintenance, Yonge St and Times Square (before revitalization), met most out of the eight physical Requirements but the degree to which those Requirements were met varies. The analysis revealed that Yonge St achieved one Requirement very well, Qualities that Engage the Eye and somewhat achieved four: Definition, Transparency, Complementarity, and Maintenance. As with Times Square, the Requirement for Places for People to Walk with Some Leisure, Physical Comfort, and Quality Design was not achieved.

Evaluation of the Five Criteria

(1) Foster Community

Yonge, similar to Times Square prior to its pedestrianization, is a popular street that is frequently visited, benefiting from access from major transit stations, a University and popular retail strip. It's a major pedestrian thoroughfare but at the same time functions as a destination for locals and tourists, facilitating interactions that is unlike other streets 
in downtown Toronto. Criteria One is somewhat achieved.

(2) Be Physically Comfortable and Safe

Pedestrian safety from vehicles is a concern for Yonge St. The heavy foot traffic already pushes people onto oncoming vehicle lanes and with intensification of condos occurring, this will likely worsen in the years to come. The crowded sidewalk particularly along the east side of Yonge is due to the narrow ROW and street furniture along the edge zone. As it is today, the sidewalks do not accommodate a comfortable walking environment. Criteria Two is not achieved.

\section{(3) Encourage Participation}

Yonge does close down for Yonge does close down for formal events like Canada Day, Car Free Day and parades, but it does not offer ample opportunities for different formal and informal activities for people to partake in. Buskers are concentrated around Dundas Square provides sonic interest and create a reason for people to stop and mingle. Aside from that the ability for others to contribute to street life remains limited. Criteria Three is somewhat achieved.

\section{(4) Be Memorable}

Yonge is unlike any other street in Toronto. Crowded sidewalks, buskers, and religious street preachers are common sights and sounds along Yonge. So too, is observing several red double decker buses parked to side with tourists spilling out onto Dundas Square. Overall Yonge benefits from the busyness of the street that attracts both locals and tourists to the area. Criteria Four is achieved very well.

\section{(5) Representative}

Yonge has long been Toronto's 'main street' and most iconic. What Yonge is today 
cannot be detached from past events and stories as the evolution of Yonge from historic retail strip, to a strip of sleaze, and a major pedestrian corridor, makes Yonge memorable and loved in Toronto. Similar to Times Square the efforts to improve Yonge over the years (Downtown Yonge BIA, 2015) reflect the effort by the City to rethink its urban policy especially with regards to public space. And the intensity and scale of residential development along Yonge are an indication of urban transformation of the City as a whole. Criteria Five is achieved very well. Criteria:

The following table (Table 8) summarizes the qualitative assessment of the five

Table 8: Qualitative Assessment of the Five Criteria for Yonge Street

\begin{tabular}{|l|l|}
\hline Criteria & Qualitative Assessment \\
\hline Foster Community & Somewhat achieved \\
\hline Physically Comfortable and Safe & Not achieved \\
\hline Encourage Participation & Somewhat achieved \\
\hline Be Memorable & Achieved very well \\
\hline Representative & Achieved very well \\
\hline
\end{tabular}

The following table (Table 9) is compares the evaluation of the five Requirements between Times Square before revitalization and Yonge St:

Table 9: Comparison of the Five Criteria between Times Square Prior to revitalization and Yonge St

\begin{tabular}{|l|l|l|}
\hline Criteria & $\begin{array}{l}\text { Times Square Qualitative } \\
\text { Assessment Before } \\
\text { Revitalization }\end{array}$ & $\begin{array}{l}\text { Yonge St Qualitative } \\
\text { Assessment }\end{array}$ \\
\hline Foster Community & Somewhat achieved & Somewhat achieved \\
\hline $\begin{array}{l}\text { Physically Comfortable and } \\
\text { Safe }\end{array}$ & Not achieved & Not achieved \\
\hline Encourage Participation & Somewhat achieved & Somewhat achieved \\
\hline Be Memorable & Achieved very well & Achieved very well \\
\hline Representative & Achieved very well & Achieved very well \\
\hline
\end{tabular}

Recap

Yonge St achieved four out of the five Criteria for Great Streets. Similar to Times Square 
before pedestrianization, the analysis found that for Yonge the two Criteria Memorable and Representative, were achieved very well while Foster Community and Encourage Participation and was somewhat achieved. Out of the five, 'Physically Comfortable and Safe' was the only Criteria not achieved on Yonge. With Yonge St not meeting three physical Requirements - Places to Walk with Some Leisure, Physical Comfort and Quality Design - it's not surprising then to see that it fell short in achieving the aforementioned Criteria. But Yonge makes up for it deficiency through its reputation as an iconic street in the City, similar to Times Square.

\section{Analysis and Conclusion}

Downtown Yonge St is a highly utilized, and well-known street. It is one of the older shopping strips in the city that benefits from being situated in the downtown core. Ryerson University, the Eaton Centre and Dundas Square act supporting nodes, drawing in thousands of people and with them a consistent energy to the street. The prevalence of heritage buildings displays visual interest and a reminder of Yonge St's past. But most, if not all are now storefronts for American food and retail chains. Improvements to Yonge could be made. The qualitative assessment of the eight Requirements suggests improving Places to Walk and as Leisure, Physical Comfort, and Quality design. The basic physical attributes that foster Great Streets do exist and it appears to benefit Yonge St. But while Yonge St remains a highly used strip it lacks the required places of quality for people to stop, pause, and sit down. As a result Yonge St, though great, functions more so as an overcrowded pedestrian thoroughfare. 


\section{CHAPTER SIX: DISCUSSION AND RECOMMENDATIONS}

\section{Discussion}

By examining Times Square before and after pedestrianization, the positive outcome of the pilot project and permanent redesign are clear. Prior to revitalization, Times Square did not achieve three out of the five physical Requirements where after subsequent efforts made marked improvements to (1) Places for People to Walk with Some Leisure; (2) Physical Comfort; and (3) Quality Design. The assessment shows changes in the three Requirements resulted in measurable improvements in three Criteria of Great Streets: Foster Community, Physically Comfortable and Safe, and Encourage Participation. Specifically changes to Times Square involved closing Broadway along 5 blocks - one of the most critical aspect of the project - thus opening up a previously vehicle congested road and reclaiming 140,000 sf for people to walk, sit, and play in comfortably and safely. Rather than simply walking through Times Square, people are invited to stay without worrying about oncoming vehicles. Large granite benches designed in manner that allows for people to use differently, add needed seating to the area. Benches accommodate several resting positions such as sitting, leaning, and lying down, which is emblematic of the focus on the pedestrian experience throughout the entire project design. Another big move was removing pavers, producing an even street grade which is important because it conveys the sense of being in a public plaza, rather than being on a blocked-off vehicle lane. The dark charcoal precast pavers embedded with nickel-size steel help balance the bright lights of Billboards while accentuating its visibility on the ground. With regards to programming, Times Square facilitates several formal events and informal uses supported by a large and flexible plaza with power access.

After examining downtown Yonge St using the evaluative framework for Great 
Streets it was found that Yonge St met the criteria of a Great Street however like Times Square before the changes, its deficiency in the same three physical Requirements, reveal an opportunity to make Yonge even Greater. Applying the five Criteria it was found that the greatest deficiency of Yonge is in providing a comfortable and safe environment for those on foot.

\section{Recommendations}

The following recommendations are based on the opportunities examined in the case studies and are informed by Allan Jacobs (1993) eight Requirements and five Criteria of Great streets. Based on the findings the following Requirements should be considered as a part of future planning and redesigns of Yonge St:

(1) Places for People to Walk with Some Leisure

- Explore opportunities to widen sidewalk through removal of traffic lane(s) which will address short-term and long-term sidewalk crowding

- Identify areas to install new seating allowing more opportunities to sit and rest

(2) Physical Comfort

- Identify areas and feasibility of street trees to be planted and planters installed.

(3) Quality Design

- Consider unique or consistent paver treatment for the sidewalk and street

- Identify Consider installing unique lighting

- Consider installing seating with unique designs

\section{Conclusion}

Informed by a literature review of public spaces and using Allan Jacob's eight Requirements and five Criteria for great streets as an evaluative framework, a case 
study was undertaken to assess the pedestrianization of Times Square and Yonge Street. This paper demonstrates how improvement to the physical Requirements of streets can result in noticeable improvement in its' function. In conclusion three recommendations were made for future planning and design considerations for Downtown Yonge Street. 


\section{REFERENCES}

Appleyard, D. (1981). Livable Streets. University of California Press, Berkley

Bagli, C. (2010, December 3). After 30 Years, Times Square Rebirth is Complete. Retrieved from https://www.nytimes.com/2010/12/04/nyregion/04square. $h t m l$ ?mtrref=www. bing.com\&gwh= 2E454521D3D29C2F98ED86C2D1539AE7\&gwt=pay

Blomley, N. (2011). Rights of Passage Sidewalks and the Regulation of Public Flow. Routledge, New York

Blomley, N. (2007). Civil rights meet civil engineering: Urban public space and traffic logic. In Canadian Journal of Law and Society 22(2) p.55-72

Cadillac Fairview (n.d.) Retrieved from https://www.cadillacfairview.com/en_CA/retailpages/cf-toronto-eaton-centre/profile.html

Catell, V., Dines, N., Gesler, W., Curtis, S. (2008). Mingling, observing, and lingering: Everyday public spaces and their implications for well-being and social relations. In Health \& Place 14 p.544-561

City of New York Department of Transportation (n.d). Retrieved from http://www.nyc.gov/ $\mathrm{html} / \mathrm{dot} / \mathrm{html} /$ pedestrians/broadway.shtml

City of New York Department of Transportation, (2013). World Class Streets. Retrieved from http://www.nyc.gov/html/dot/downloads/pdf/2013-dot-sustainable-streets-4- worldclassstreets.pdf

City of New York Department of Transportation. (2010). Green Light for Midtown Evaluation Report. Retrieved from http://www.nyc.gov/html/dot/downloads/pdf/broadway_report_final2010_web2.pdf

City of New York (2011). PlaNYC A Greener, Greater New York. Retrieved from http:// www.nyc.gov/html/planyc/downloads/pdf/publications/planyc_2011_planyc_full_repor t.pdf

City of New York (n.d.) Department of Transportation Sustainable Streets http://www. nyc.gov/html/dot/html/about/stratplan.shtml

City of New York (2008) Department of Transportation Sustainable Streets Strategic Plan for the New York City Department of Transportation 2008 and Beyond http://www. nyc.gov/html/dot/downloads/pdf/stratplan_intro.pdf

City of New York (n.d.) Department of City Planning http://www1.nyc.gov/site/planning/ index.page 
City of Toronto. (2017). Complete Streets Guidelines. Making Streets for People, Placemaking and Prosperity. Retrieved from http://www1.toronto.ca/wps/portal/contentonly?vgnextoid=bdb604f82477d410VgnVCM1000 0071d60f89RCRD

City of Toronto (2017, August 15). Yonge and Gerrard Focus Area Review. Retrieved from https://www.toronto.ca/legdocs/mmis/2017/te/bgrd/backgroundfile-106307.pdf

City of Toronto (2013). Tall Buildings Design Guidelines. Retrieved from: https://www. toronto.ca/legdocs/mmis/2013/pg/bgrd/backgroundfile-57177.pdf

City of Toronto (2012, August 8). Downtown Yonge Street Studies Staff Report. Retrieved from https://www.toronto.ca/legdocs/mmis/2012/te/bgrd/backgroundfile-49619. pdf

City of Toronto (n.d.). Downtown Parks and Public Realm Strategy Retrieved from https://www.toronto.ca/wp-content/uploads/2017/12/949d-city-planningtocore-parks-and-public-realm-plan-summary-final.pdf

Cresswell, J.W., Hanson, W.E., Plano Clark, V.L., Morales, A. (2007). Qualitative research designs: selection and implementation in The Counseling Psychologist, 35(2) p.236-264 DOI: 10.1177/0011000006287390

De Certeau, M. (1984). The Practice of Everyday Life. Berkely \& London: University of California Press

De Vasconcellos, E.A., (2004). The use of streets: A reassessment and tribute to Donald Appleyard. In Journal of Urban Design, 9(1) p.3-22. DOI: $10.1080 / 1357480042000187686$

Dines, N., Cattell, V., \& Curtis, S. (2006). Public spaces, social relations and well-being in east London. Retrieved from https://www.jrf.org.uk/file/37153/download?token=Fv8CzcUB\&filetype=full...

Cached

Downtown Yonge BIA (2015). Yonge Love Report. Retrieved from http://www.yongelove. ca/YongeLove_Report.pdf

Ehrenfeucht, R. (2017). Do food trucks and pedestrians conflict on urban streets. In Journal of Urban Design 22(2) p.273-290

Ehrenfeucht, R., \& Loukaitou-Sideris, A. (2010). Planning urban sidewalks: Daily life and destinations. The Production of Public Space. Vol 15(4), 459-471.

Fraser, L. (2017, June 22). Murder of Emanuel Jaques changed the face of Yonge Street and Toronto. Retrieved from http://www.cbc.ca/news/canada/toronto/emanu- 
el-jaques-yonge- street-sex-work-1.4172511

Garcia, A., Lydon., M. (2015) Tactical Urbansim Short-Term Action for Long-Term Change. Island Press

Gehl, J. (2011). Life Between Buildings. Island Press

Gehl, J., \& Gemzoe, L. (2004). Public Spaces Public Life Copenhagen. Narayana Press, Denmark

Gehl People (n.d.) Unrolling a welcome mat for the people of New York. Retrieved from: http://gehlpeople.com/cases/new-york-usa/

Goheen, P.G. (1994). Negotiating access to public space in mid-nineteenth century Toronto . In Journal of Historical Geography 20(4) p.430-449

Great. N.d. In Merriam-Webster.com. Retrieved from https://www.merriam- webster. com/dictionary/great

Hess, P.M. (2009). Avenues or arterials: The struggles to change street building practices in Toronto Canada. In Journal of Urban Design 14(1) p.1-28

Jacobs, A.B. (1993). Great Streets. MIT Press Paperback Jacobs, J. (1961). The Death and Life of Great American Cities. Random House, New York Katz, E.R. (2017, June 1). Times Square's 8-Year Resdesign is a Blueprint for the City of the

Future. MIC. Retrieved from: https://mic.com/articles/177463/times-squares-8-year-redesign- is-a-blueprint-for-the-city-of-the-future\#.Jr8JwSkZQ

Kettel, G. (2016, July 6). Yonge St. corridor can't handle more development. Retrieved from https://www.thestar.com/opinion/commentary/2016/07/06/yonge-st-corridor-canthandle- more-development.html

Kim, A. (2012). The mixed-use sidewalk: Vending and property right in public space. Journal of American Planning Association Vol 78(3) p.225-238.

Kohn, M. (2004). Brave New Neighbourhoods: The Privatization of Public Space. New York: Routledge

KPMB Architects \& Greenburg Consultants Inc (2011, June). Yonge Street Planning Lang, M.L., Camp, J.K. (2004). The Athenian Citizen: Democracy in the Athenian Agora. Princeton, New Jersey: American School of Classical Studies

Lang, J., Marshall, N. (2016). Urban Squares as Places, Links and Displays: Successes 
and Failures. Routledge

Lofland. L. (1973). A World of Strangers. Basic Books Inc: New York

Loukaitou-Sideris, A., Levy-Storms, L., Chen, L., \& Brozen, M. (2016). Parks for an aging population: Needs and preferences of low-iicome seniors in Los Angeles. Journal of the American Planning Association, 82(3), 236-251.

Luberoff, D. (2016). Reimagining and Reconfiguring New York City's Streets. Retrieved from http://research.gsd.harvard.edu/tut/files/2016/02/NYC-Case-1-21-161.pdf

Magel, R. (1998). 200 years Yonge: a history. Dundern: Toronto

Makagon, D. (2003). A search for social connection in America's town square: Times square and urban public life in Southern Journal of Communication 69(1) p.1-21. DOI https://doi.org/10.1080/10417940309373275

Malone, D. (2017, April 20) The Snohetta-designed project nearly doubles the size of public spaces at one of the most visited attractions in the U.S. Building Design \& Construction.

Retrieved from: https://www.bdcnetwork.com/times-square-renovation-officially-opens

Mangomap (n.d.) The Buildings of Manhattan. The correlation between building age and height. Retrieved from: https://mangomap.com/mango-chris/maps/11955/The\%20Correlation\%20Between $\% 20$ Building $\% 20$ Height $\% 20$ and\%20Building\%20Age $\% 20$ in $\% 20$ Manhattan\#

Mandanipour, A. (2010). Whose Public Space International Case Studies in Urban Design and Development. Routledge Taylor and Fracis Group. London \& New York

Mazumdar, S., Learnihan, V., Cochrane, T., Davey, R. (2018). The Built environment and social capital: a systematic review in Environment and Behavior 50(2) p.119-158. doi/10.1177/0013916516687343

Mehta, V. (2014). The Street A Quintessential Social Public Space. Routledge

Minutillo, J. (2017, April 19). Times Square Reconstruction by Snohettera. Retrieved from https://www.architecturalrecord.com/articles/12613-times-square-reconstruction-by- sn\%C3\%B8hetta

Mould, O. (2014) Tactical Urbanism: The new vernacular of the creative city. Geography Compass Vol 8(9) p.529-539.

Orzeck, R. (2002). Recreation: Urban revitalization and Toronto's Yonge street. 
Osuldsen, J.B. (2017, August 2). Snohetta. Retrieved from https://www.oppland.no/Handlers/fh.ashx?Mld1=108\&Filld=4632

Owen, D. (2013, January 21). The Psychology of Space. Retrieved from https://www. newyorker.com/magazine/2013/01/21/the-psychology-of-space

Peters, K., Elands, B., Bujis, A. (2010). Social interactions in urban parks: Stimulating social cohesion? In Urban Forestry \& Urban Greenings Vol 9 p.93-100. doi:10.1016/j. ufug.2009.11.003

Radywyl, N., Biggs, C. (2013). Reclaiming the commons for urban transformation. In Journal of Cleaner Production 50(2013) 19-170. http://dx.doi.org/10.1016/j.jclepro.2012.12.020

Rannila, P., \& Mitchell, D. (2016). Syracuse, sidewalks, and snow: the slippery realities of public space. In Urban Geography 37(7) p.1070-1090

Rhodes, M. (2015, October 16). The benches are the coolest part of Times Square's redesign. Retrieved from https://www.wired.com/2015/10/the-benches-are-the-coolestpart-of-times- squares-redesign/

Ross, D.G. (2017). Remaking downtown Toronto: Politics, development and public space on Yonge Street, 1950-1980

Ryerson University (n.d.) Retrieved from https://www.ryerson.ca/about/

Sadik-Khan, J., \& Solomonow, S. (2017). Street Fight Handbook for an Urban Revolution. Penguin Press, New York.

Snohetta designs 2.5 acres of pedestrian-only space in Manhattan's Times Square (2017, April 27). Retrieved from: https://www.building.ca/construction/snohetta-designs2-5-acres- pedestrian-space-manhattans-times-square/1003736055/

Southworth, M. (2014). Public life, public space, and the change art of city design. In Journal of Urban Design 19(1), p.37-40. doi: http://dx.doi.org/10.1080/13574809.2014.8 54684

Times Square Business Improvement District. (1996). Times Square BID Annual Report. Retrieved from http://www.timessquare.nyc/about-the-alliance/annual-and-financial- reports/download.aspx?id=86

Times Square Alliance (2008). Problems and Possibilities. Retrieved from https://issuu. com/designtrustforpublicspace/docs/problems_and_possibilities_times_square

Times Square 2006-2007 (n.d.) Retrieved from https://www.pps.org/projects/ timessquare 
Timessquarenyc (n.d). https://www.timessquarenyc.org/

Varna, G. (2014). Measuring Public Space: The star model. University of Glasgow: UK Watson, S. (2006). City Publics: the (Dis)enchantments of Urban Encounters. UK: Routledge.

Williams, K., Green, S. (2001). Literature review of public space and local environments for the cross cutting review. Retrieve from http://johannes.lecture.ub.ac.id/files/2012/09/ Literature- Review-of-Public-Space-and-Local-Environments-for-the-Cross-Cutting-Review.pdf

World Health Organization (2007) Global Age-friendly Cities: A Guide. Community Health, 77. https://doi.org/http://whqlibdoc.who.int/publications/2007/9789241547307_ eng.pdf?ua $=1$

Yin, R.K. (1999). Enhancing the quality of case studies in health services research in Health Services Research 34(5) Pt 2 p.1209-1224.

Young, I.M. (1990). Justice and the Politics of Difference. Princeton University Press. Princeton, New Jersey

Yum, K. (1998, November 4). A crusade to heal the streets. Retrieved from https://theeyeopener.com/1998/11/a-crusade-to-heal-the-streets/ 